\title{
Spatial evapotranspiration, rainfall and land use data in water accounting - Part 1: Review of the accuracy of the remote sensing data
}

\author{
P. Karimi ${ }^{1}$ and W. G. M. Bastiaanssen ${ }^{1,2,3}$ \\ ${ }^{1}$ UNESCO-IHE Institute for Water Education, Delft, the Netherlands \\ ${ }^{2}$ International Water Management Institute, Battaramulla, Sri Lanka \\ ${ }^{3}$ Faculty of Civil Engineering and Geosciences, Water Management Department, Delft University of Technology, \\ Delft, the Netherlands
}

Correspondence to: P. Karimi (p.karimi@Unesco-ihe.org)

Received: 20 November 2013 - Published in Hydrol. Earth Syst. Sci. Discuss.: 22 January 2014

Revised: 5 December 2014 - Accepted: 12 December 2014 - Published: 28 January 2015

\begin{abstract}
The scarcity of water encourages scientists to develop new analytical tools to enhance water resource management. Water accounting and distributed hydrological models are examples of such tools. Water accounting needs accurate input data for adequate descriptions of water distribution and water depletion in river basins. Ground-based observatories are decreasing, and not generally accessible. Remote sensing data is a suitable alternative to measure the required input variables. This paper reviews the reliability of remote sensing algorithms to accurately determine the spatial distribution of actual evapotranspiration, rainfall and land use. For our validation we used only those papers that covered study periods of seasonal to annual cycles because the accumulated water balance is the primary concern. Review papers covering shorter periods only (days, weeks) were not included in our review. Our review shows that by using remote sensing, the absolute values of evapotranspiration can be estimated with an overall accuracy of $95 \%$ (SD $5 \%$ ) and rainfall with an overall absolute accuracy of $82 \%$ (SD $15 \%$ ). Land use can be identified with an overall accuracy of $85 \%$ (SD $7 \%$ ). Hence, more scientific work is needed to improve the spatial mapping of rainfall and land use using multiple space-borne sensors. While not always perfect at all spatial and temporal scales, seasonally accumulated actual evapotranspiration maps can be used with confidence in water accounting and hydrological modeling.
\end{abstract}

\section{Introduction}

The demand for fresh water is increasing worldwide due to economic and population growth (Molden et al., 2007; Vörösmarty et al., 2010). Proper planning of such scarce water resources in terms of storage, allocation, return flow and environmental services is vital for optimizing the resource (Chartres and Varma, 2010). There is, however, a lack of fundamental data on vertical and lateral water flows, water stocks, water demand, and water depletion. At the same time, there is a decline in the network density of operational hydrometeorological field stations. The absence of adequate field data sets is an important obstacle for sound, evidence-based water resource management decisions. The consequence of data scarcity is more severe in transboundary river basins where, apart from collection, the accessibility of data is hindered by political issues (Awulachew et al., 2013).

Remotely sensed hydrological data are an attractive alternative to conventional ground data collection methods (Bastiaanssen et al., 2000; Engman and Gurney, 1991; Wagner et al., 2009; Neale and Cosh, 2012). Satellites measure the spatial distribution of hydrological variables indirectly with a high temporal frequency across vast river basins. There are many public data archives where every user can download preprocessed satellite data. Quality flags are often provided, as well as manuals with explanations on how the satellite data have been preprocessed and can be reproduced. These recurrent data sets are highly transparent, politically neutral and consistent across entire river basins, even for large basins 
such as the Nile and the Ganges. While certain satellite data sets have been processed to a first level of reflectance, emittance, and backscatter coefficients, others will even provide second level products that can be directly explored for water resource planning purposes (e.g., land cover, soil moisture, and rainfall). Evapotranspiration (ET) is one of the parameters that often requires additional processing of the spectral data; only a very few public domain data archives provide preprocessed ET data and, in fact, spatial ET modeling is still underdeveloped. Examples of several remotely sensed ET algorithms that could be applied to interpret raw satellite data into spatial layers of ET are well summarized in a recent book edited by Irmak (2012).

Time series of various hydrological variables such as precipitation, evapotranspiration, snow cover, soil moisture, water levels, and aquifer storage can be downloaded from public domain satellite-based data archives. With the right analytical tools and skills, these abundant data sets of hydrological processes can be used to produce information on water resource conditions in river basins. Tools such as Water Accounting Plus (WA+) (Karimi et al., 2013a, b) are expressly designed to exploit remote sensing estimates of hydrological variables. Water accounting is the process of communicating water related information about a geographical domain, such as a river basin or a country, to users such as policy makers, water authorities, basin managers, and public users. Water accounting information can be key to river basin management policy, especially when administrations are reluctant to share their - sometimes imperfect - in situ data with neighboring states and countries. WA + can facilitate conflict management in internationally shared river basins. In addition to that, hydrological variables derived from remote sensing can also be used for spatially distributed hydrological modeling. Studies by Houser et al. (1998), Schuurmans et al. (2003), and Immerzeel and Droogers (2008) have, for instance, demonstrated that such inputs have improved hydrological model performance for river basins in Australia, the Netherlands and India, respectively.

A major point of criticism that is commonly laid down on remote sensing data has been the lack of accuracy. With the improvement of technology the accuracy has however improved significantly over the last 30 years; yet it is necessary to remain critical. It is important to note that the conventional methods of measuring hydrological processes (e.g., rainfall and discharge) are not flawless either and, thus, the accuracy of both types of measurements needs to be verified. There are also limitations with what conventional measurement methods can offer especially when spatially distributed data is concerned. For instance, the actual ET of river basins can hardly be measured operationally through ground measurements; therefore, the depletion of water remains difficult to estimate and quantify. Thus, ET is often ignored in water accounting frameworks such as the SEEA-Water system proposed by the United Nations Statistics Division (UN, 2007) and the Australian water accounting system (ABS, 2004).
Remote sensing techniques, however, can provide spatially distributed daily estimates of actual ET and this opens new pathways in the accounting of water depletion (Karimi et al., 2013a).

This paper investigates the errors and reliability of remotely sensed ET, rainfall, and land use based on a comprehensive literature review. The choice of the variables that have been investigated in this paper (ET, rainfall, land use/land cover) is based on the common use in hydrological and water resource management studies. Only recent publications on accumulated ET and rainfall for a minimum time period of one growing cycle have been consulted, which implies that some of the well-known reference papers are excluded because they relate to shorter flux observation periods. Elder remote sensing algorithms were also excluded. The companion paper (Karimi et al., 2015) investigates impacts of the errors associated with the satellite measurement for ET, rainfall and land use on the accuracy of WA+ outputs, using a case study from the Awash Basin in Ethiopia. See Appendix $\mathrm{D}$ for a glossary of the abbreviations used throughout the paper.

\section{Remote sensing data for water accounting (WA+)}

\subsection{Evapotranspiration}

Over the past decades several methods and algorithms to estimate actual ET through satellite measurements have been developed. Most of these estimates are based on the surface energy balance equation. The surface energy balance describes the partitioning of natural radiation absorbed at Earth's surface into physical land surface processes. Evapotranspiration is one of these key processes of the energy balance, because latent heat (energy) is required for evaporation to take place. The energy balance at Earth's surface reads

$\mathrm{LE}=R_{\mathrm{n}}-G-H\left(\mathrm{Wm}^{-2}\right)$,

where $R_{\mathrm{n}}$ is the net radiation, $G$ is the soil heat flux, $H$ is the sensible heat flux, and LE is the latent heat flux. The sensible heat flux $H$ is a function of the temperature difference between the canopy surface and the lower part of the atmosphere, and the soil heat flux $G$ is a similar function related to the temperature difference between the land surface and the top soil. A rise of surface temperature will thus usually increase $H$ and $G$ fluxes. Evaporative cooling will reduce $H$ and $G$, and result in a lower surface temperature. The LE is the equivalent energy amount $\left(\mathrm{W} \mathrm{m}^{-2}\right)$ of the ET flux $\left(\mathrm{kg} \mathrm{m}^{-2} \mathrm{~s}^{-1}\right.$ or $\left.\mathrm{mm} \mathrm{d}^{-1}\right)$. The net radiation absorbed at the land surface is computed from shortwave and long-wave radiation exchanges. Solar radiation is shortwave and is the most important supplier of energy. More information on the energy balance is provided in general background material such as Brutsaert (1982), Campbell and Norman (1998) or Allen et al. (1998). 
Surface temperature is measured routinely by spaceborne radiometers such as the Advanced Very High Resolution Radiometer (AVHRR), Moderate Resolution Imaging Spectrometer (MODIS), Visible Infrared Imager Radiometer Suite (VIIRS), Landsat, Advanced Space borne Thermal Emission and Reflection Radiometer (ASTER), ChinaBrazil Earth Resources Satellite (CBERS), and the Chinese HJ and Feng Yung satellites. Remotely sensed surface temperature is the major input variable in ET algorithms. Examples of thermal infrared ET algorithms are provided by EARS (Rosema, 1990), SEBAL (Bastiaanssen et al., 1998), TSEB (Norman et al., 1995), SEBS (Su, 2002; Jia et al., 2003), METRIC (Allen et al., 2007), ALEXI (Anderson et al., 1997), and ETWatch (Wu et al., 2012). The differences among these algorithms are often related to the parameterization of $H$, general model assumptions, and the amount of input data required to operate these models.

Other groups of ET algorithms are based on the vegetation index and its derivatives such as published by Nemani and Running (1989), Guerschman et al. (2009), K. Zhang et al. (2010), Mu et al. (2011), and Miralles et al. (2011). ETLook (Bastiaanssen et al., 2012) is a new ET model that directly computes the surface energy balance using surface soil moisture estimations for the top soil (to feed soil evaporation) and subsoil moisture for the root zone (to feed vegetation transpiration). Soil moisture data can be inferred from thermal measurements (e.g., Scott et al., 2003) or from microwave measurements (e.g., Dunne et al., 2007). Microwave measurements provide a solution for all weather conditions and can be applied at any spatial scale for which moisture data is available.

A different school of remote-sensing-based ET algorithms is built around the derivation of a relative value of ET using trapezoid/triangle methods. Trapezoid/triangle diagrams are constructed from a population of pixel values of surface temperature and vegetation index and used to infer the relative value of ET (e.g., Choudhury, 1995; Moran et al., 1994; Roerink et al., 2000; Wang et al., 2007). In these diagrams, the range of surface temperature values at a given class of vegetation index is the basis for determining relative ET, assuming that the lowest temperature in a certain range of vegetation index represents potential ET. The highest temperature coincides with zero evaporation. The main assumption in triangle/trapezoidal methods is that the variation in vegetation index relation to surface temperature is driven primarily by the variation in soil water content rather than differences in atmospheric conditions.

Merging different global ET products such as MOD16 (Mu et al., 2011) and ERA-Interim (Dee et al., 2011) at global and regional scales into one ET product is another approach that has been used by a group of scientists. This approach mainly uses statistical methods to combine ET products that are based on different methods, algorithms, and origins (e.g., global: Mueller et al., 2013; Africa: Trambauer et al., 2014; US: Velpuri et al., 2013). New ensemble ET prod- ucts on the basis of several open access and global-scale operational ET products from Earth observations are under development, but are not published yet.

Review papers on advanced algorithms for estimating spatial layers of ET have been published by Moran and Jackson (1991), Kustas and Norman (1996), Bastiaanssen (1998), Courault et al. (2005), Glenn et al. (2007), Gowda et al. (2007), Kalma et al. (2008), Verstraeten et al. (2008), and Allen et al. (2011). While these review papers provide a good understanding of the evolution of ET algorithm development, they rarely report the accuracies attainable, especially at a seasonal or longer time frame.

\subsection{Rainfall}

There are different algorithms to infer rainfall from satellite data. The four essentially different technologies are (i) indexing the number and duration of clouds (Barrett, 1988), (ii) accumulated cold cloud temperatures (Dugdale and Milford, 1986), (iii) microwave emissivity (Kummerow et al., 1996), and (iv) radar reflectivity (Austin, 1987). Techniques using microwave wavelength information are promising alternatives for measuring rainfall because of the potential for sensing the raindrops themselves and not a surrogate of rain, such as the cloud type. Microwave radiation with wavelengths in the order of $1 \mathrm{~mm}-5 \mathrm{~cm}$ has a strong interaction with raindrops, since the drop size of rain is comparable to this wavelength. This feature makes them suitable to detect rainfall intensity. Active microwave (radar) measurements of rainfall are based on the Rayleigh scattering caused by the interaction of rain and the radar signal (Cracknell and Hayes, 1991). Spaceborne radar measurements of rain intensity are possible with the precipitation radar (PR) aboard the NASA Tropical Rainfall Measuring Mission (TRMM) and Global Precipitation Mission (GPM) satellites, which assesses the attenuation of the radar signal caused by the rain. The PR has a pixel size of $5 \mathrm{~km}$ and can oversee a swath of $220 \mathrm{~km}$. Unfortunately, it is usually necessary to evaluate the rainfall radar reflectivity factor empirically on a region-by-region basis over lengthy periods of time. In other words, rain radar systems both ground-based and satellite-based - need calibration for proper rainfall estimates. We will conclude later that most papers investigated in our review process do apply a certain level of field calibration. Several operational rainfall products based on satellite measurements have been created or improved more recently. Among the new ensemble rainfall products is the Climate Hazards Group InfraRed Precipitation Station (CHIRPS) that provides promising results (Funk et al., 2013).

Review papers on the determination of rainfall from satellite measurements have been prepared, by, for instance, Barrett (1988), Barrett and Beaumont (1994), Petty (1995), Petty and Krajewski (1996), Kummerow et al. (1996), Smith et al. (1998), Kidd (2001), Stephens and Kummerow (2007), and Huffman et al. (2007). A selection of available rainfall 
Table 1. Overview of the main existing regional and global-scale satellite-based data sources of rainfall. The column "gauge" indicates whether a calibration against ground data is included.

\begin{tabular}{|c|c|c|c|c|c|c|}
\hline Product & Main principle data & Resolution & $\begin{array}{l}\text { Spatial } \\
\text { coverage }\end{array}$ & Gauge & $\begin{array}{l}\text { Minimum } \\
\text { time steps } \\
\text { interval }\end{array}$ & Producer \\
\hline MPE & Meteosat 7, 8, 910 & $3 \mathrm{~km}$ & Indian ocean & $N$ & $15 \mathrm{~min}$ & EUMETSAT \\
\hline CMORPH & $\begin{array}{l}\text { Microwave estimates (DMSP F-13, } 14 \& \\
15 \text { (SSM/I), NOAA-15, 16, } 17 \& 18 \\
\text { (AMSU-B), AMSR-E, and TRMM } \\
\text { (TMI), IR motion vectors }\end{array}$ & $8 \mathrm{~km}$ & $50^{\circ} \mathrm{N}-50^{\circ} \mathrm{S}$ & $N$ & $30 \mathrm{~min}$ & NOAA/CPC \\
\hline PERSIANN & $\begin{array}{l}\text { Microwave estimates (DMSP F-13, } 14, \& \\
15, \text { NOAA-15, 16, 17, and TRMM } \\
(\mathrm{TMI}))\end{array}$ & $0.25^{\circ}$ & $60^{\circ} \mathrm{N}-60^{\circ} \mathrm{S}$ & $N$ & $1 \mathrm{~h}$ & UC Irvine \\
\hline GSMap & $\begin{array}{l}\text { Microwave estimates (DMSP F-13, } 14 \& \\
15 \text { (SSM/I), AMSR, AMSR-E, and } \\
\text { TRMM (TMI)) }\end{array}$ & $0.1^{\circ}$ & $60^{\circ} \mathrm{N}-60^{\circ} \mathrm{S}$ & $N$ & $1 \mathrm{~h}$ & JAXA \\
\hline $\begin{array}{l}\text { NRL- } \\
\text { blended }\end{array}$ & $\begin{array}{l}\text { Microwave estimates (DMSP F-13, 14, \& } \\
15 \text { (SSM/I), F-16 (SSMIS)) }\end{array}$ & $0.25^{\circ}$ & $60^{\circ} \mathrm{N}-60^{\circ} \mathrm{S}$ & $N$ & $3 \mathrm{~h}$ & NRL \\
\hline TCI (3G68) & $\begin{array}{l}\text { Microwave estimates (TRMM (TMI)), } \\
\text { and PR }\end{array}$ & $0.5^{\circ}$ & $37^{\circ} \mathrm{N}-37^{\circ} \mathrm{S}$ & $N$ & $1 \mathrm{~h}$ & NASA \\
\hline TOVS & HIRS, MSU sounding retrievals & $1^{\circ}$ & Global & $N$ & Daily & NASA \\
\hline $\begin{array}{l}\text { Hydro } \\
\text { estimator }\end{array}$ & GOES IR & $4 \mathrm{~km}$ & Global & $N$ & $15 \mathrm{~min}$ & NOAA \\
\hline TRMM 3B42 & $\begin{array}{l}\text { Microwave estimates (TRMM, SSM/I, } \\
\text { AMSR and AMSU), IR estimates from } \\
\text { geostationary satellites }\end{array}$ & $0.25^{\circ}$ & $50^{\circ} \mathrm{N}-50^{\circ} \mathrm{S}$ & $Y$ & $3 \mathrm{~h}$ & NASA \\
\hline CPC-RFE2.0 & $\begin{array}{l}\text { Microwave estimates (SSM/I, AMSU-B), } \\
\text { IR estimates from METEOSAT }\end{array}$ & $0.1^{\circ}$ & $\begin{array}{l}20^{\circ} \mathrm{W}-55^{\circ} \mathrm{E} \\
40^{\circ} \mathrm{S}-40^{\circ} \mathrm{N}\end{array}$ & $Y$ & Daily & FEWS \\
\hline GPCP 1DD & $\begin{array}{l}\text { IR estimates from geostationary satellites, } \\
\text { TOVS }\end{array}$ & $1^{\circ}$ & $50^{\circ} \mathrm{N}-50^{\circ} \mathrm{S}$ & $Y$ & Daily & NASA/GSFC \\
\hline CMAP & Microwave estimates (SSM/I), GOES IR & $2.5^{\circ}$ & Global & $Y$ & 5 days & NOAA \\
\hline TAMSAT & Meteosat thermal-IR & $3 \mathrm{~km}$ & Africa & $Y$ & 10 days & $\begin{array}{l}\text { Reading } \\
\text { University }\end{array}$ \\
\hline TRMM 3B43 & $\begin{array}{l}\text { Microwave estimates (TRMM, SSM/I, } \\
\text { AMSR and AMSU), IR estimates from } \\
\text { geostationary satellites }\end{array}$ & $0.25^{\circ}$ & $40^{\circ} \mathrm{N}-40^{\circ} \mathrm{S}$ & $Y$ & Monthly & NASA \\
\hline GPCP_V2 & Microwave estimates (SSM/I), IR, TOVS & $2.5^{\circ}$ & Global & $Y$ & Monthly & NASA/GSFC \\
\hline
\end{tabular}

products based on remote sensing techniques - sometimes used in combination with other methodologies - is presented in Table 1.

\subsection{Land use}

Whereas land cover describes the physical properties of vegetation (e.g., grass, savannah, forest), land use denotes the usage of that land cover (e.g., pasture, crop farming, soccer field). Maps of land use are fundamental to WA+ be- cause it determines the services and processes in a spatial context. Different types of land use provide benefits and services such as food production (agricultural land), economic production (industrial areas), power generation (reservoirs), environmental ecosystems (wetlands), livelihoods etc., and they have an associated water consumptive use. Land use classification based on the use of water, differs from classical land use land cover maps that focus mainly on the description of woody vegetation such as forests and shrubs for ecological and woodland management purposes. WA+ needs 
land use maps focused on crop types (e.g., rainfed potatoes, irrigated maize) and the source of water consumed (e.g., surface water and groundwater). Some of the first maps dedicated for agricultural water management were prepared by Thenkabail et al. (2005), Cheema and Bastiaanssen (2010), Yalew et al. (2012) and Kiptala et al. (2013). Furthermore, land use classifications for $\mathrm{WA}+$ at river basin scale require a pixel size of $30-100 \mathrm{~m}$ that can be delivered by Landsat8 and Proba-V satellite data, respectively. It is expected that the arrival of Sentinel-2 data during the course of 2014 with pixel sizes ranging between $10-30 \mathrm{~m}$ and a short revisit time of 5 days will greatly enhance development of new land use classifications that are tailored for water use and water accounting.

Land use changes affect the water balance of river basins and thus also the amount of water flowing to downstream areas. Bosch and Hewlett (1982) and Van der Walt et al. (2004) discuss for instance how replacing natural vegetation by exotic forest plantations reduced the stream flow in South Africa. Maes et al. (2009) evaluated the effect of land use changes on ecosystem services and water quantity on basins in Belgium and Australia. The role of land use is thus a crucial component of sound water accounting and water resource management (Molden, 2007).

Land use is usually identified on the basis of spectral reflectance and its change with vegetation phonology. The reflectance in the near and middle infrared part of the electromagnetic spectrum, especially, is often related to certain land use classes. The relationship between reflectance and land use is however not unique, and field inspections are usually needed for better interpretation. Soil type, soil moisture and surface roughness all have an influence on reflectance. The health of the vegetation and factors such as the angle and size of leaves also affect the photosynthetic activity of the plants. There is another land use mapping technology that is entirely based on the difference in time profiles of spectral vegetation indices. Fourier analysis of vegetation index can be used to quantify land use classes and crop types (e.g., Roerink et al., 2003), especially when time profiles are linked to existing cropping calendars.

All the land use classification papers we reviewed report on a confusion matrix that describes the overall classification accuracy by showing how often certain land use classes are confused in the remote sensing analysis with other land use classes. Congalton (1991) and Foody (2002) give a full explanation on errors in land use data.

Review papers on the use of remote sensing for land use land cover classification are provided in Bastiaanssen (1998), Smits et al. (1999), Mucher et al. (2000), Cihlar (2000), Franklin and Wulder (2002), Thenkabail et al. (2009b), and García-Mora et al. (2012).

\section{Results}

\subsection{Accuracy of spatial evapotranspiration data}

The lack of validation of spatial layers of ET is one of the drawbacks in defining the reliability of remotely sensed ET products. There are no reliable and low-cost ground-based ET flux measurement techniques, although new inventions are always underway (Euser et al., 2014). It is simply too costly to install instruments that have the capacity to measure ET operationally at various locations dispersed across a river basin. The main methods to measure ET at the field scale include lysimeters, Bowen ratio, eddy covariance systems, surface renewal systems, scintillometers, and classical soil water balancing. Lysimeters can be very accurate for in situ measurements of ET at small scale if they are properly maintained. Bowen ratio and eddy covariance flux towers and surface renewal systems are fairly accurate methods for estimating ET at scales of up to $1 \mathrm{~km}$ (Rana and Katerji, 2000), although not free of errors (e.g., Teixeira and Bastiaanssen, 2010; Twine et al., 2000). Scintillometers have the capability to measure fluxes across path lengths of 5-10 km (Hartogensis et al., 2010; Meijninger and de Bruin, 2000).

To deal with the problem of measuring ET fluxes in a composite terrain, large-scale field experiments in the African continent (e.g., Sahel: Goutorbe et al., 1997; southern Africa: Otter et al., 2002), the European continent (e.g., France: Andre et al., 1986; Spain: Bolle et al., 2006), the American continent (e.g., Kansas: Smith et al., 1992; Arizona and Oklahoma: Jackson et al., 1993) and the Asian continent (e.g., China: Wang et al., 1992: Korea: Moon et al., 2003) were set up to measure fluxes simultaneously within a certain geographic region at a number of sites with different land use classes. Several remotely sensed ET algorithms were developed and validated using these data sets. The limitation is however that the duration of these field campaigns was for budgetary reasons restricted to several weeks only.

Validation studies with different ET algorithms using the same spatial ground truth data sets are very interesting. The International Water Management Institute (IWMI) undertook for instance a validation study to determine the accuracy of various ET methods for irrigated cotton and grapes in Turkey (Kite and Droogers, 2000). Although here the period was not sufficiently long to encompass one growing season. The Commonwealth Science and Industrial Research Organisation (CSIRO) in Australia studied the predictions of eight different ET products, at a minimum monthly frequency and at a spatial resolution of at least $5 \mathrm{~km}$, using flux tower observations and watershed data across the entire continent as part of the Water Information Research and Development Alliance (WIRADA) project (Glenn et al., 2011). The studied ET products were based on different methods including largescale water balance modeling, thermal imagery (Mcvicar and Jupp, 1999, 2002), spectral imagery (Guerschman et al., 2009), inferred LAI (leaf area index; Y. Zhang et al., 2010), 
passive microwave (Bastiaanssen et al., 2012), and the global MODIS reflectance-based algorithm (Mu et al., 2007). The results showed that at annual-scale remote-sensing-based ET estimates, barring the global MODIS product that was at the time an unrefined method that needed improvements $(\mathrm{Mu}$ et al., 2011), had an acceptable mean absolute percentage error (MAPE) ranging from 0.6 to $18 \%$ with an average MAPE of $6 \%$ (King et al., 2011). Along similar lines, the Council for Scientific and Industrial Research (CSIR) in South Africa conducted a remote sensing study on a smaller scale to investigate the performance of three ET algorithms (Jarmain et al., 2009).

To assess the overall error in accumulated ET products, a comprehensive literature review was conducted and reported errors by various authors were synthesized. All the papers included in the review were published within the past 13 years (hence from the year 2000 onwards) and they cover a range of in situ measurements and remote sensing ET algorithms. The reviewed papers cover a range of remote sensing methods for ET measurements including SEBAL, METRIC, SEBS, TSEB, ALEXI, ET Watch, and SatDAET. In essence, the spatial ET layers reported in these papers were not a priori calibrated and the authors reported on the validation aspect. Since the primary purpose of this study was to quantify errors in accumulated ET, only papers that report errors on ET estimates over a minimum period of one growing cycle which on average is about 5-6 months, hereafter called seasonal ET, were consulted. Papers dealing with ET over shorter periods were thus excluded in our review (e.g., Anderson et al., 2011; Chávez et al., 2008; Gonzalez-Dugo et al., 2009; Mu et al., 2011). This, also, implies that GEWEX (Global Energy and Water Exchanges Project)-related field experiments could not be used because intensive campaigns with multiple flux covered periods of weeks only. The manifold flux campaigns organized by the US Department of Agriculture (Kustas et al., 2006; JORNEX: Rango et al., 1998; SALSA: Chehbouni et al., 1999) also did not meet our criterion. To be able to compare error levels from different studies only papers that report errors in terms of mean error were included in the review. Thus, some of the valuable papers on this topic that use RMSE (root mean square error) to describe errors without including mean error could not be included in the review (e.g., Batra et al., 2006; Cleugh et al., 2007; Guerschman et al., 2009; Venturini et al., 2008). The data sources consulted are summarized in Appendix A. It reflects the accumulated ET conditions encountered in 11 countries. Thirty-one publications met the criteria specified and were analyzed. One publication often contains more data points due to multiple models, multiple years, and multiple areas. Hence, the total number of points was $n=46$. Considering this number, the probability density function is unlikely to change if other papers - or more papers - were to be considered in the review.

The probability distribution of mean absolute percentage error in remote sensing ET estimates is presented in Fig. 1.

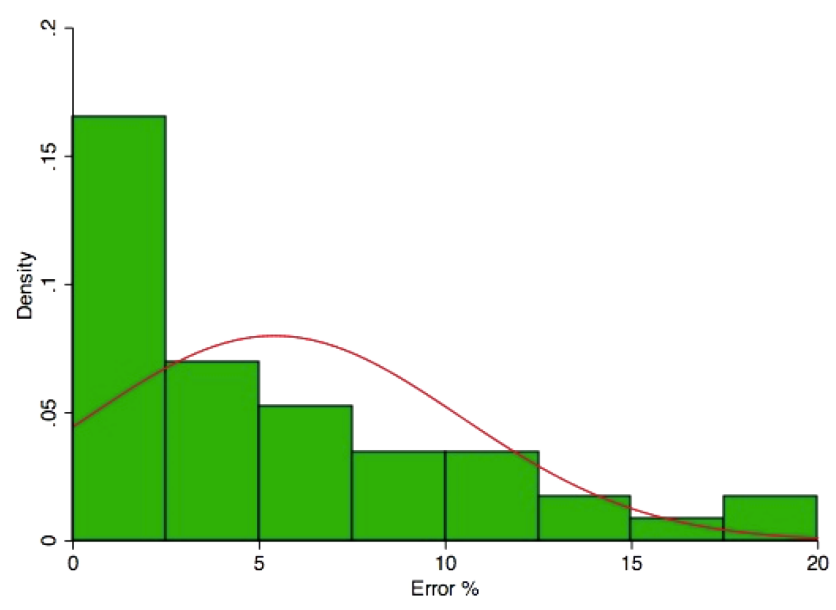

Figure 1. Probability density function of the reported mean absolute percentage error in remotely sensed ET estimates. A season or longer period was considered.

The results demonstrate the absolute error of annual or seasonal ET to vary between 1 and $20 \%$. The average MAPE is $5.4 \%$, with a standard deviation of $5.0 \%$. It is evident from Fig. 1 that the distribution is positively skewed. These results are closely in line with findings by King et al. (2011) in Australia, both in terms of average and the range of error in ET estimates.

Many of the publications reported an error of less than $5 \%$, a remarkable good and unexpected result. In many cases, the authors of the papers were both the developers and the testers of the algorithms, and parameter tuning was possible. The left-hand bar in Fig. 1 is, we believe, a biased view of the reality. For this reason, the data points were fitted by means of a skewed normal distribution so that less weight is given to the class with exceptionally low errors.

There are seven papers that report a mean absolute percentage error of $1 \%$ for the ET of cropland. Without exception, all these papers are based on the Surface Energy Balance Algorithm for Land (SEBAL) and its related algorithm Mapping ET at High Resolution with Internalized Calibration (METRIC). Apparently, these algorithms work well for crops, which was recognized earlier by Bastiaanssen et al. (2009) and Allen et al. (2011). Another interesting observation is that at river basin scale - i.e., the scale where water accounting is done - all papers report a MAPE of less than $5 \%$. These case studies include the $3 \%$ difference between the measured ET and remotely sensed ET of selected river basins in Sri Lanka (Bastiaanssen and Chandrapala, 2003), $1.7 \%$ difference observed by Singh et al. (2011) for the Midwest in the USA using the METRIC algorithm, 1.8 and $3 \%$ differences observed by Wu et al. (2012) using ET Watch in the Hai Basin of the North China Plain, $5 \%$ difference observed by Bastiaanssen et al. (2002) for the Indus Basin, $1 \%$ difference observed by Evans et al. (2009) for the MurrayDarling Basin, and 0.6, 2.1, 3.9, and 18\% differences for 
different algorithms observed by King et al. (2011) for the Australian continent.

At the other end of the spectrum, the largest ET deviations were found by Jiang et al. (2009) for alkali scrubs in south Florida. They used the SatDAET algorithm which is an ET estimation method that uses the contextual relationship between remotely sensed surface temperature and vegetation index to calculate evaporative fraction $(\mathrm{EF})$. They compared the estimated ET using SatDAET for both clear and cloudy days with ET from lysimeters and observed a $19 \%$ difference for 1999.

There is no single preferred ET model. The selection of the algorithm depends on the application, the required spatial resolution, the period for which the ET fluxes should be estimated for, the size of the study area, the land use classes present, etc. A useful distinction is to discern global-scale models (few) and local-scale models (many). Also, the level of validation and application of these models widely differ. Whereas certain models are tested with a single experimental flux site, other models have been applied in more than 30 countries.

Considering this positive evaluation, spatial layers of ET should be encouraged for applications in water accounting and hydrological modeling. Except for Jhorar et al. (2011), Winsemius et al. (2008) and Rientjes et al. (2013), this is rarely done because water managers and hydrologists do not accept ET layers as being sufficiently accurate. This new analysis proves that the science of remote sensing in the last 13 years has advanced and that mapping of ET has become more reliable.

\subsection{Accuracy of spatial rainfall data}

A comprehensive literature review - similar to ET - was conducted for remote sensing rainfall products. Twenty-four peer reviewed papers that describe the accuracy of annual and seasonal rainfall from satellites, published over the last 5 years were reviewed (see Appendix B). Sixty-eight data points were reconstructed from these publications. The selected papers used various remote sensing rainfall products including TRMM, PERSIANN, RFE, ERA40, CMORPH, and CMAP. A common problem is the scale mismatch between rain gauges and the area integrated rainfall of one single microwave-based pixel of the satellite image.

Several of these papers compared different rainfall algorithms. Some also used the same field data to verify several rainfall algorithms. For example, Asadullah et al. (2008) compared five satellite-based rainfall estimates (SRFEs) with historical average rainfall data from gauges over the period 1960-1990 in Uganda. The difference between gauged data and SRFEs was found to vary between 2 and $19 \%$. Products such as CMORPH, TRMM 3B42, TAMSAT, and RFE underestimated rainfall by $2,8,12$, and $19 \%$, respectively, while PERSIANN overestimated by $8 \%$. Stisen and Sanholt (2010) compared three global SRFE products,

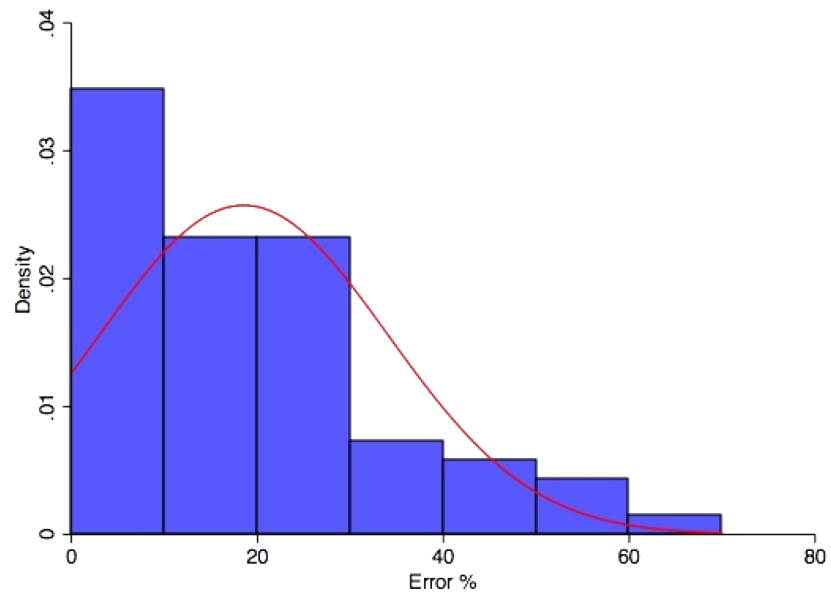

Figure 2. Probability density function of the reported mean absolute percentage error in rainfall estimates from remote sensing. A season or longer period is considered.

i.e., CMORPH, TRMM 3B42 and PERSIANN, and two SRFEs made for Africa, i.e., CPC-FEWS v2 and a locally calibrated product based on TAMSAT data, with the average gauge rainfall in Senegal River basin. They concluded that rainfall estimation methods that are designed for Africa significantly outperform global products. This superior performance is attributed both to the inclusion of local rain gauge data and to the fact that they are made specifically for the atmospheric conditions encountered on the African continent. Of the global products, SRFEs from TRMM were found more accurate, presumably because monthly calibration of the $3 \mathrm{~B} 43$ product is a default process of the algorithm. The global SRFEs showed an improved performance after bias correction and recalibration. The positive effects of the inclusion of rain gauge data in SRFEs is also reported in the study by Dinku et al. (2011), which compared five SRFEs with rain gauge data in the Blue Nile Basin. Several studies show that local calibration significantly improves the accuracy of satellite-based rainfall estimates: Almazroui et al. (2012) in Saudi Arabia, Cheema and Bastiaanssen (2012) in the Indus Basin, Duan and Bastiaanssen (2013) in the Lake Tana and Caspian Sea regions, and Hunink et al. (2014) in the highelevation Tungurahua Province in the Andes mountain range of Ecuador.

The error probability distribution function curve reconstructed from the a priori calibrated rainfall data set is shown in Fig. 2. The mean absolute percentage error varies between 0 and $65 \%$, and the average MAPE for calibrated satellite rainfall estimates is $18.5 \%$. The standard deviation is $15.4 \%$, with a positive skewness of 0.9 . As with the density function for ET, the curve fitting of the distribution was forced with a skewed normal distribution to ensure that less weight is assigned to the class of $0-10 \%$ deviation. This indicates that for the majority of case studies, the error in calibrated rainfall maps is less than $18.5 \%$. Large error bands were found 


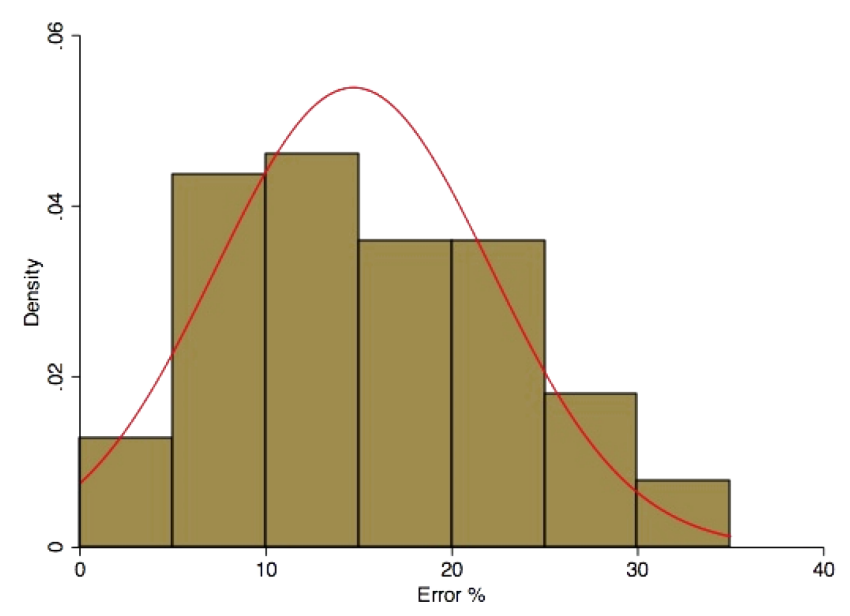

Figure 3. Probability density function of the reported mean absolute percentage error in land use classification using remote sensing.

for all rainfall algorithms, and no particular algorithm performs better in terms of variance. The unresolved problem of the pixel-gauge-scale mismatch is one major source of this problem. The average MAPE is $14,17,21,23,28$, and $29 \%$ for TRMM, ERA40, GPCP 1DD, CMORPH, RFE, and PERSIANN, respectively. These average values represent the average MAPE of each SRFE regardless of the product version.

The interim conclusions are therefore that (i) the processes to derive rainfall from satellite data are more complex than the derivation of ET and (ii) that the performance of existing rainfall products is not satisfactory and requires caution when applied for water accounting and hydrological modeling, despite the fact that most SRFEs have an a priori calibration procedure. More research and development of operational rainfall algorithms using various types of sensors is deemed necessary.

\subsection{Accuracy of land use land cover maps}

The publications listed in Appendix C were reviewed for land use estimations. Sixty-five papers were reviewed. Seventyeight data points were reconstructed from these papers. Rather diverging land use classes and data from 35 different countries were included in this comparative data set. The results are presented in Fig. 3. The shape of the probability density function of error differs from the ones obtained for ET and rainfall: it is tending towards a standardized normal distribution, which implies that the number of very good results and very poor results are similar. Table 2 provides a summary of the statistical results. The mean absolute percentage error, defined as 1 minus overall accuracy, for land use classification is $14.6 \%$, with a standard deviation of $7.4 \%$ and a skewness of 0.35 .

The overall performance is rather good, and this can be partially explained by the fact that high-resolution satellites
Table 2. Mean deviation of the input variables and the distribution of the error.

\begin{tabular}{llrrcc}
\hline $\begin{array}{l}\text { Remote } \\
\text { sensing } \\
\text { parameter }\end{array}$ & Calibration & $\begin{array}{r}\text { Mean } \\
\text { absolute } \\
\text { percentage } \\
\text { error } \\
(\%)\end{array}$ & $\begin{array}{r}\text { Standard } \\
\text { deviation } \\
\text { error } \\
(\%)\end{array}$ & $\begin{array}{r}\text { Skewness } \\
(-)\end{array}$ & $\begin{array}{c}\text { No. of } \\
\text { data } \\
\text { points }\end{array}$ \\
\hline ET & No & 5.4 & 4.9 & 1.18 & 41 \\
Rainfall & Yes & 18.5 & 15.4 & 0.90 & 69 \\
Land use & Yes & 14.6 & 7.4 & 0.37 & 78 \\
\hline
\end{tabular}

were often used for the land use and land cover classification. The spectral measurements of Landsat and Aster satellites were especially often applied because they have bands suitable for the detection of a range of land use classes in the near- and middle-infrared part of the spectrum. To investigate the impact of the spatial resolution of the used imagery on the accuracy of the land use product, we divided the data points into two groups based on the reported resolution. The MAPE for land use classifications that are based on high-resolution images, $30 \mathrm{~m}$ and less, is $12.9 \%$, whereas for those that use moderate- and low-resolution images, more than $200 \mathrm{~m}$, the MAPE is $19.8 \%$. The number of land use classes shows no significant impact on the overall accuracy of the map. The results reveal that the global-scale land cover maps have lower overall accuracy due to their large pixel size. The overall accuracies of global maps varies between 69 and $87 \%$ with an average of $76.4 \%$, which is equivalent to a MAPE of 13$31 \%$ and average of $23.4 \%$. This observation shows that global land cover maps should be used with caution in water accounting applications.

The overall accuracy in the reviewed papers varies between 68 and $98 \%$. This is in good agreement with the suggested range of 70-90\% by Bach et al. (2006) in their review paper. The review also revealed that Landsat products, with 42 case studies out of the total 78 , are the most commonly used imagery for land use land cover classification purposes. The free access Landsat- 8 data may thus set the directions for near future development of land use classifications, especially when being complemented with Sentinel data. The Finer Resolution Observation and Monitoring - Global Land Cover (Gong et al., 2013) is an example of that.

Many land use studies are based on ground truth data sets that are used for controlling or supervising the classification process. The data in Appendix $\mathrm{C}$ thus have an element of a priori calibration which increases the overall accuracy. Without ground truthing, the overall calibration can be expected to be lower. Also, it must be noted that only the overall accuracy of the confusion matrix is used. While the overall accuracy might be acceptable, it is likely that the error in certain individual land use classes is significantly different. 


\section{Conclusions and way forward}

The increasing number of satellite-based measurements of land and water use data are provided by generally accessible data archives, although evapotranspiration data sets are under development. Satellites provide spatial information with a high temporal frequency over wide areas, which make remotely sensed maps of land use and hydrological variables an attractive alternative to conventionally collected data sets. However, the uncertainty about the possible errors in remote sensing estimates has been an ongoing concern among the users of these products. The goal of this study was to investigate the errors and reliability of some of these remotely sensed hydrological variables created by advanced algorithms through an international literature review. Only recent data sets, not older than 13 years, were reviewed.

The main interest of this review was to understand the measure of error in remote sensing data for water accounting. The review focused on ET, precipitation, and land use classifications. A comprehensive literature review was conducted and for each variable several numbers of post-2000 peer-reviewed publications were consulted for reported differences between satellite-based estimates from conventional ground measurements. It is important to note that conventional ground measurements come with their own errors and uncertainty that should ideally be taken in consideration when used for verifying the accuracy of satellite-based estimates. This holds true for ET where the number of operational flux towers is limited, but also for rainfall that has distinct microscale variability and cannot be measured by a single gauge. However, in most documented studies these ground measurements are treated as "the best available estimates" in the absence of reliable information on their accuracy. As such, they are widely used to validate satellite-based data. The probability distribution functions of the mean absolute percentage errors for all three variables were created, and these functions have more value than a single research paper, with a single algorithm applied to a particular location.

The results show that the average MAPE for satellitebased estimates of annual or seasonal ET, rainfall, and land use classification are $5.4,18.5$, and $14.6 \%$, respectively. The largest error is thus associated with rainfall. Bias correction and local calibration of global and regional rainfall products seem to improve the quality of the data layers. However, more research is needed to improve remotely sensed rainfall estimation algorithms (e.g., CHIRPS), with a focus on downscaling procedures as the standard pixel size is often too large. Radar-based regional precipitation estimates that offer higher spatiotemporal resolutions are promising and need to be utilized further. Also, the attenuation of microwave signals between cellular communication networks can be used for assessing areal averaged rainfall. In addition, given the differences among reported precipitation measurements by different global and regional products for the same pixels, there is a need for a database that offers an ensemble based on a rigorous and statistically sound method.

In contrast to rainfall, the error in satellite-based ET is relatively small, especially at the aggregation level of a river basin. ET is a vital component of hydrological cycle and reliable estimates of local ET are the essential for modeling river basin hydrology accurately. Remotely sensed ET can be used both as input to distributed hydrological models, and as a means to calibrate the simulations, although locally large errors can occur. Nonetheless, despite its existing potential and accuracy, satellite-based ET is underutilized in hydrological studies. Contributing factors are presumably the difficulty to access and acquire reliable ET data through the public domain, and the difficulty to compare it with reliable field data. Thus, future focus should be on development of open access ET databases. Such efforts are now underway by various organizations such as the US Geological Survey, US Department of Agriculture, the Commonwealth Science and Industrial Research Organization of Australia and the Chinese Academy of Sciences. However, these products have not yet been made fully available to the public, albeit first estimates of an ensemble ET product are under development. There is also a need for higher-resolution ET data in terms of both spatial and temporal resolutions. This is a key factor if satellite-based ET data are to be used extensively in water management and hydrological studies.

Land use mapping was one of the earliest ways in which satellite imagery was used to produce environmental information and it is the most widely studied subject employing remote sensing. The quality of the classifications has improved over time by the availability of high-resolution images and local research projects. The low-resolution and operational land classification mapping product is, however, still the standard method. Global high-resolution land use and land cover databases are conceived as the next generation of information systems for WA+ and other applications, and the product created by Tsinghua University is a first example. The land use classifications come with an overall MAPE of $14.6 \%$, and accuracy of $85 \%$. This level of accuracy, although acceptable, calls for improvements given the wide use of these maps. Another important issue is the need for a new type of land use mapping dedicated to agricultural and river basin water management issues. This is of essential value when land use maps are used in hydrological and water management-related studies such as water accounting.

As revealed by the results of this review study, there is a great deal of heterogeneity regarding the accuracy and reliability of remote sensing data and methods. Oftentimes the reliability of remote-sensing-based products is rather case and location specific. Future research could, therefore, aim at cross-comparing remote sensing data and methods on ET, rainfall and land use for different regions. Ensemble mean ET products are currently under development. 
Appendix A: Literature review on evapotranspiration

Table A1. Selected ET validation papers that describe experimental data sets covering a season or longer.

\begin{tabular}{|c|c|c|c|c|c|c|}
\hline Method & $\begin{array}{l}\text { Field } \\
\text { instrument }\end{array}$ & Location and year & Land use & $\begin{array}{l}\text { No. of } \\
\text { images }\end{array}$ & Source & $\begin{array}{l}\text { MAPE } \\
(\%)\end{array}$ \\
\hline METRIC & Lysimeter & Idhao, US, 1985 & Native sedge forage & 4 & Allen et al. (2005) & 4 \\
\hline METRIC & Lysimeter & Idaho, US, 1989 & Sugar beet & 12 & Allen et al. (2007) & 1 \\
\hline ALEXI & Eddy covariance & New Mexico, US, 2008 & Agricultural areas & 6 & Anderson et al. (2012) & 6.7 \\
\hline SEBAL & Water balance & Sri Lanka & River basin & - & Bastiaanssen and Chandrapala (2003) & 1 \\
\hline SEBAL & Water balance & Indus, Pakistan & River basin & 20 & Bastiaanssen et al. (2002) & 5 \\
\hline SEBAL & Lysimeter & California, US, 2002 & Alfalfa & 7 & $\begin{array}{l}\text { F. Cassel and M. Robertson } \\
\text { (personal communication, } \\
\text { 2006) }\end{array}$ & 2 \\
\hline SEBAL & Lysimeter & California, US, 2002 & Peaches & 7 & $\begin{array}{l}\text { F. Cassel and M. Robertson } \\
\text { (personal communication, } \\
\text { 2006) }\end{array}$ & 7 \\
\hline SEBAL & Water balance & $\begin{array}{l}\text { Murray-Darling } \\
\text { Basin, Australia }\end{array}$ & River Basin & - & Evans et al. (2009) & 1 \\
\hline NDVI-based model & $\begin{array}{l}\text { Eddy } \\
\text { covariance }\end{array}$ & New Mexico, US & $\begin{array}{l}\text { Cottonwood, } \\
\text { saltcedar }\end{array}$ & 10 & Groeneveld et al. (2007) & 2.2 \\
\hline NDVI-based model & Bowen ratio & Colorado, US, 2006 & $\begin{array}{l}\text { Greasewood, } \\
\text { salt rabbitbrush }\end{array}$ & 5 & Groeneveld et al. (2007) & 12.2 \\
\hline NDVI-based model & $\begin{array}{l}\text { Eddy } \\
\text { covariance }\end{array}$ & $\begin{array}{l}\text { California, US, 2000- } \\
2002\end{array}$ & $\begin{array}{l}\text { Salt grass, alkali } \\
\text { sacaton }\end{array}$ & 9 & Groeneveld et al. (2007) & 12.5 \\
\hline SEBAL & Water balance & Central Luzon, 2001 & Rice & 3 & Hafeez et al. (2002) & 10.5 \\
\hline SEBAL & Scintillometer & Horana, 1999 & $\begin{array}{l}\text { Palm trees } \\
\text { and rice }\end{array}$ & 5 & $\begin{array}{l}\text { Hemakumara and } \\
\text { Chandrapala (2003) }\end{array}$ & 0.9 \\
\hline METRIC & Bowen ratio & Nebraska, US, 2005 & Corn & 4 & Irmak et al. (2011) & 4.3 \\
\hline METRIC & Bowen ratio & Nebraska, US, 2006 & Corn & 4 & Irmak et al. (2011) & 4.2 \\
\hline SEBAL & Water balance & $\begin{array}{l}\text { Western Cape, } \\
\text { South Africa } \\
2004-2006\end{array}$ & Grapes & 12 & Jarmain et al. (2007) & 12 \\
\hline ETWatch & Water balance & $\begin{array}{l}\text { Hai Basin, China - } \\
\text { 2002-2009 }\end{array}$ & Basin & 135 & Jia et al. (2012) & 8.3 \\
\hline SatDAET & Lysimeter & Florida, US, 1998 & Alkali scrub & 8 & Jiang et al. (2009) & 14 \\
\hline SatDAET & Lysimeter & Florida, US, 1999 & Alkali scrub & 3 & Jiang et al. (2009) & 19 \\
\hline CMRS1 & Water balance & Australia & River basin & NA & King et al. (2011) & 2.1 \\
\hline CMRS2 & Water balance & Australia & River basin & NA & King et al. (2011) & 0.6 \\
\hline NDTI & Water balance & Australia & River basin & NA & King et al. (2011) & 18 \\
\hline ETLooK & Water balance & Australia & River basin & NA & King et al. (2011) & 3.9 \\
\hline SEBAL & Scintillometer & $\begin{array}{l}\text { Gediz Basin, } \\
\text { Turkey, } 1998\end{array}$ & Grapes, cotton & 4 & Kite and Droogers (2000) & 16 \\
\hline SEBAL & $\begin{array}{l}\text { Surface } \\
\text { renewal }\end{array}$ & $\begin{array}{l}\text { Sacramento Valley, } \\
\text { US, } 2001\end{array}$ & Rice & 8 & Lal et al. (2012) & 1 \\
\hline TSEB & Measurements & $\begin{array}{l}\text { Yellow River, } \\
\text { China, } 2004\end{array}$ & Wetlands & - & Li et al. (2012) & 7.9 \\
\hline SEBS & Measurements & Australia, 2009 & $\begin{array}{l}\text { Irrigated } \\
\text { agriculture }\end{array}$ & 16 & Ma et al. (2012) & 7.5 \\
\hline
\end{tabular}


Table A1. Continued.

\begin{tabular}{|c|c|c|c|c|c|c|}
\hline Method & $\begin{array}{l}\text { Field } \\
\text { instrument }\end{array}$ & Location and year & Land use & $\begin{array}{l}\text { No. of } \\
\text { images }\end{array}$ & Source & $\begin{array}{l}\text { MAPE } \\
(\%)\end{array}$ \\
\hline METRIC/SEBAL & Water balance & India, 2003 & $\begin{array}{l}\text { Irrigated } \\
\text { agriculture }\end{array}$ & 40 & Mallick et al. (2007) & 11.6 \\
\hline SEBAL & Water balance & Sudd, Sudan, 2000 & Wetland & - & Mohamed et al. (2004) & 1.8 \\
\hline SEBAL & Water balance & Sobat, Sudan, 2000 & Wetland & - & Mohamed et al. (2004) & 5.7 \\
\hline SEBAL & Water balance & California, US, 2002 & Almonds & 7 & $\begin{array}{l}\text { B. L. Sanden (personal } \\
\text { communication, 2005) }\end{array}$ & 1 \\
\hline SEBAL & Bowen ratio & Nebraska, US & Corn & 7 & Singh et al. (2008) & 5 \\
\hline METRIC & $\begin{array}{l}\text { Eddy } \\
\text { covariance }\end{array}$ & Nebraska, US & River basin & 8 & Singh et al. (2011) & 1.7 \\
\hline SEBAL & Water balance & California, US & $\begin{array}{l}\text { Irrigated } \\
\text { agriculture }\end{array}$ & 5 & Soppe et al. (2006) & 1 \\
\hline SEBAL & Lysimeter & $\begin{array}{l}\text { Idaho, US, } \\
\text { 1989-1991 }\end{array}$ & Irrigated agriculture & 11 & Tasumi et al. (2003) & 4.3 \\
\hline SEBAL & $\begin{array}{l}\text { Eddy } \\
\text { covariance }\end{array}$ & $\begin{array}{l}\text { Petrolina, } \\
\text { 2001-2007 }\end{array}$ & Mango, grapes & 9 & Teixeira et al. (2008) & 1 \\
\hline SEBAL & $\begin{array}{l}\text { Eddy } \\
\text { covariance }\end{array}$ & Brazil & $\begin{array}{l}\text { Natural } \\
\text { vegetation and } \\
\text { irrigated crops }\end{array}$ & 18 & Teixeira et al. (2009) & 1 \\
\hline SEBAL & Water balance & $\begin{array}{l}\text { Imperial Valley, } \\
1997-1998\end{array}$ & Several & 12 & Thoreson et al. (2009) & 1 \\
\hline SEBAL & $\begin{array}{l}\text { Eddy } \\
\text { covariance }\end{array}$ & $\begin{array}{l}\text { Middle Rio Grande, } \\
\text { US, 2002-2003 }\end{array}$ & Pecan, alfalfa & 7 & Wang and Sun (2005) & 3 \\
\hline ETWatch & Lysimeter & $\begin{array}{l}\text { Hai Basin, China, } \\
\text { 2002-2005 }\end{array}$ & $\begin{array}{l}\text { Wheat-maize } \\
\text { rotation }\end{array}$ & - & Wu et al. (2012) & 9 \\
\hline ETWatch & $\begin{array}{l}\text { Eddy } \\
\text { covariance }\end{array}$ & $\begin{array}{l}\text { Hai Basin, China, } \\
\text { 2002-2005 }\end{array}$ & River Basin & 20 & Wu et al. (2012) & 3 \\
\hline ETWatch & Water balance & $\begin{array}{l}\text { Hai Basin, China, } \\
\text { 2002-2005 }\end{array}$ & River basin & - & Wu et al. (2012) & 1.8 \\
\hline SEBAL & Water balance & North district, China & Regional scale & 26 & Yang et al. (2012) & 5.6 \\
\hline WUE*-based model & $\begin{array}{l}\text { Eddy } \\
\text { covariance }\end{array}$ & $\begin{array}{l}\text { Jilin Province, } \\
\text { China } 2003\end{array}$ & Mixed forest & 45 & Zhang et al. (2009) & 4 \\
\hline WUE-based model & $\begin{array}{l}\text { Eddy } \\
\text { covariance }\end{array}$ & $\begin{array}{l}\text { Jilin Province, } \\
\text { China } 2004\end{array}$ & Mixed forest & 45 & Zhang et al. (2009) & 2 \\
\hline WUE-based model & $\begin{array}{l}\text { Eddy } \\
\text { covariance }\end{array}$ & $\begin{array}{l}\text { Jilin Province, } \\
\text { China } 2005\end{array}$ & Mixed forest & 45 & Zhang et al. (2009) & 0.4 \\
\hline
\end{tabular}

* water use efficiency 
Appendix B: Literature review on rainfall

Table B1. Selected validation papers that describe experimental data sets covering a season or longer.

\begin{tabular}{|c|c|c|c|c|}
\hline Source & Area & Year & RS data source & Deviation \\
\hline Almazroui et al. (2011) & Saudi Arabia & 1998-2008 & TRMM & 0 \\
\hline Almazroui et al. (2012) & Saudi Arabia & 1998-2008 & TRMM & 12.05 \\
\hline Asadullah et al. (2010) & Uganda & 2003-2007 & CMORPH & 2 \\
\hline Asadullah et al. (2010) & Uganda & 2003-2007 & PERSIANN & 8 \\
\hline Asadullah et al. (2010) & Uganda & 2003-2007 & RFE 2.0 & 19 \\
\hline Asadullah et al. (2010) & Uganda & 2003-2007 & TRMM 3B42 & 8 \\
\hline Asadullah et al. (2010) & Uganda & 2003-2007 & TAMSAT & 12 \\
\hline Bitew and Gebremichael (2011) & Gilgel, Ethiopia & 2006-2007 & CMORPH & 29 \\
\hline Bitew and Gebremichael (2011) & Gilgel, Ethiopia & 2006-2007 & TRMM 3B42RT & 29 \\
\hline Bitew and Gebremichael (2011) & Gilgel, Ethiopia & 2006-2007 & PERSIANN & 58 \\
\hline Bitew and Gebremichael (2011) & Gilgel, Ethiopia & 2006-2007 & TRMM 3B42 & 64 \\
\hline Cheema and Bastiaanssen (2012) & Indus & 2007 & TRMM 3B43 V6 & 6.1 \\
\hline Cheema and Bastiaanssen (2012) & Indus & 2007 & TRMM 3B43 V6 & 10.9 \\
\hline Chen et al. (2011) & Dongjing Basin, China & 2002-2010 & TRMM 3B42RT & 22.1 \\
\hline Collischonn et al. (2008) & Tapajo’s Basin, Brazil & 1997-2006 & TRMM 3B42 & 12 \\
\hline Dinku et al. (2007) & Ethiopian Highlands & 1998-2004 & TRMM 3B43 & 8 \\
\hline Dinku et al. (2011) & Blue Nile, Ethiopia & 1981-2004 & CMAP & 3 \\
\hline Dinku et al. (2011) & Blue Nile, Ethiopia & 1981-2004 & GPCP & 5 \\
\hline Dinku et al. (2011) & Blue Nile, Ethiopia & 2003-2004 & CMORPH & 1 \\
\hline Dinku et al. (2011) & Blue Nile, Ethiopia & 2003-2004 & TRMM 3B42 & 5 \\
\hline Dinku et al. (2011) & Blue Nile, Ethiopia & 2003-2004 & RFE & 48 \\
\hline Duan and Bastiaanssen (2013) & Lake Tana & 1999, 2000, 2004 & TRMM 3B43 V7 & 1 \\
\hline Duan and Bastiaanssen (2013) & Caspian Sea, Iran & 2000-2003 & TRMM 3B43 V7 & 20 \\
\hline Feidas (2009) & Greece & 1998-2006 & TRMM 3B42 & 4.2 \\
\hline Feidas (2009) & Greece & 1998-2007 & TRMM 3B43 & 7.6 \\
\hline Feidas (2009) & Greece & 1998-2008 & GPCP-1DD & 28.7 \\
\hline Fernandes et al. (2008) & Amazon Basin, South America & 1980-2002 & ERA-40 & 10 \\
\hline Fernandes et al. (2008) & Amazon Basin, South America & 1980-2002 & GPCP & 7 \\
\hline Fu et al. (2011) & Poyang Basin, China & 2003-2006 & GSMaP & 54 \\
\hline Getirana et al. (2011) & Negro Basin, South America & 1998-2002 & TMPA & 18 \\
\hline Getirana et al. (2011) & Negro Basin, South America & 1998-2002 & NCEP-2 & 13 \\
\hline Getirana et al. (2011) & Negro Basin, South America & 1998-2002 & ERA-40 & 18 \\
\hline Jiang et al. (2012) & Mishui Basin, China & 2003-2008 & CMORPH & 41 \\
\hline Jiang et al. (2012) & Mishui Basin, China & 2003-2008 & 3B42RT & 43 \\
\hline Jiang et al. (2012) & Mishui Basin, China & 2003-2008 & 3B42V6 & 4.54 \\
\hline Kizza et al. (2012) & Lake Victoria & 2001-2004 & TRMM 3B43 & 5 \\
\hline Kizza et al. (2012) & Lake Victoria & 2001-2004 & PERSIANN & 1 \\
\hline Milewski et al. (2009) & Egypt & & TRMM & 15 \\
\hline Moffitt et al. (2011) & Bangladesh & 2000-2005 & TRMM 3B42V6 & 11.6 \\
\hline Pierre et al. (2011) & Sahelian belt & 2004-2007 & RFE 2.0 & 23 \\
\hline Pierre et al. (2011) & Sahelian belt & 2004-2007 & TRMM 3B42 & 6 \\
\hline Pierre et al. (2011) & Sahelian belt & 2004-2007 & CMORPH & 34 \\
\hline Semire et al. (2012) & Malaysia & 2001-2010 & TRMM 3B43 V6 & 15 \\
\hline Stisen and Sandholt (2010) & Senegal River basin & 2003-2005 & CMORPH & 34 \\
\hline Stisen and Sanholt (2010) & Senegal River basin & 2003-2005 & PERSIANN & 47 \\
\hline Stisen and Sanholt (2010) & Senegal River basin & 2003-2005 & TRMM & 23 \\
\hline Stisen and Sanholt (2010) & Senegal River basin & 2003-2005 & $\mathrm{CCD}$ & 6 \\
\hline Stisen and Sanholt (2010) & Senegal River basin & 2003-2005 & CPC-FEWs & 21 \\
\hline Su et al. (2008) & La Plata Basin & 1998-2006 & TRMM & 6 \\
\hline Villarini et al. (2009) & Oklahoma, USA & 1998-2003 & TRMM & 10 \\
\hline Voisin et al. (2008) & Amazon & 1997-1999 & ERA-40 & 26.5 \\
\hline
\end{tabular}


Table B1. Continued.

\begin{tabular}{lllll}
\hline Source & Area & Year & RS data source & Deviation \\
\hline Voisin et al. (2008) & Amazon & $1997-1999$ & GPCP 1DD & 24.7 \\
Voisin et al. (2008) & Mississippi, USA & $1997-1999$ & ERA-40 & 32.3 \\
Voisin et al. (2008) & Mississippi, USA & $1997-1999$ & GPCP 1DD & 25.3 \\
Voisin et al. (2008) & Mackenzie, Canada & $1997-1999$ & ERA-40 & 1.1 \\
Voisin et al. (2008) & Mackenzie, Canada & $1997-1999$ & GPCP 1DD & 28.8 \\
Voisin et al. (2008) & Congo, Africa & $1997-1999$ & ERA-40 & 13.4 \\
Voisin et al. (2008) & Congo, Africa & $1997-1999$ & GPCP 1DD & 31 \\
Voisin et al. (2008) & Danube, Europe & $1997-1999$ & ERA-40 & 29.1 \\
Voisin et al. (2008) & Danube, Europe & $1997-1999$ & GPCP 1DD & 17.1 \\
Voisin et al. (2008) & Mekong, SEA & $1997-1999$ & ERA-40 & 0.4 \\
Voisin et al. (2008) & Mekong, SEA & $1997-1999$ & GPCP 1DD & 4.1 \\
Voisin et al. (2008) & Senegal & $1997-1999$ & ERA-40 & 51.6 \\
Voisin et al. (2008) & Senegal & $1997-1999$ & GPCP 1DD & 23.3 \\
Voisin et al. (2008) & Yellow River, China & $1997-1999$ & ERA-40 & 1.3 \\
Voisin et al. (2008) & Yellow River, China & $1997-1999$ & GPCP 1DD & 30.4 \\
Voisin et al. (2008) & Yenisei, Russia & $1997-1999$ & ERA-40 & 0.7 \\
Voisin et al. (2008) & Yenisei, Russia & $1997-1999$ & GPCP 1DD & 26.2 \\
Wilk et al. (2006) & Okavango Basin & $1991-1996$ & TRMM & 20 \\
\hline
\end{tabular}


Appendix C: Literature review on land use and land cover

Table C1. Selected validation papers that report on confusion matrices.

\begin{tabular}{|c|c|c|c|c|}
\hline Source & Area & $\begin{array}{l}\text { Image } \\
\text { year }\end{array}$ & Image source & $\begin{array}{c}\text { Overall } \\
\text { accuracy } \\
(\%)\end{array}$ \\
\hline Abd El-Kawy et al. (2011) & Nile Delta, Egypt & 2005 & Landsat ETM+ & 96 \\
\hline Aguirre-Gutiérrez et al. (2012) & Sierra Madre, Mexico & 2006 & Landsat ETM+ & 87 \\
\hline Bach et al. (2006) & Erda, Germany & 1989-1992 & $\begin{array}{l}\text { CORINE } \\
\text { (Landsat TM) }\end{array}$ & 75 \\
\hline Bach et al. (2006) & Erda, Germany & 1994 & Landsat-5 TM & 79 \\
\hline Bach et al. (2006) & Stein, Germany & 1989-1992 & CORINE (Landsat TM) & 69 \\
\hline Bach et al. (2006) & Stein, Germany & 1994 & Landsat-5 TM & 74 \\
\hline Bicheron et al. (2008) & Global & 2004-2006 & MERIS/Envisat & 73 \\
\hline Blanco et al. (2013) & Latin America & 2008 & Modis-Terra & 84 \\
\hline Büttner et al. (2006) & Global & 1999-2000 & $\begin{array}{l}\text { Landsat } \\
\text { ETM+/SPOT }\end{array}$ & 87 \\
\hline Cassidy et al. (2013) & Lower Mekong & 2005 & Landsat TM & 85 \\
\hline Cheema and Bastiaanssen (2010) & Indus Basin & 2007 & SPOT/vegetation & 77 \\
\hline Cingolani (2004) & Cordoba, Argentina & 1997 & Landsat 5 TM & 86 \\
\hline Clark et al. (2010) & $\begin{array}{l}\text { Dry Chaco, South } \\
\text { America }\end{array}$ & 2000-2008 & MODIS & 80 \\
\hline Colditz et al. (2012) & Mexico & 2005 & MODIS & 83 \\
\hline Hubert-Moy et al. (2001) & $\begin{array}{l}\text { Baie de Lannion, } \\
\text { France }\end{array}$ & 1996-1997 & Landsat 5TM & 89 \\
\hline Estes et al. (2012) & $\begin{array}{l}\text { Serengeti National } \\
\text { Park }\end{array}$ & $2002-2003$ & Landsat ETM+ & 83 \\
\hline Friedl et al. (2010) & Global & 2000-2001 & Modis 5 & 75 \\
\hline Gamanya et al. (2007) & Central Zimbabwe & 2001 & ASTER & 92 \\
\hline Gamanya et al. (2007) & Central Zimbabwe & 2001 & Landsat TM & 89 \\
\hline Kandrika and Roy (2008) & Orissa, India & 2004-2005 & AWiFS IRS-P6 & 87 \\
\hline Kavzoglu and Colkesen (2009) & Kocaeil, Turkey & 1997 & Landsat ETM+ & 91 \\
\hline Kavzoglu and Colkesen (2009) & Kocaeil, Turkey & 1997 & Landsat ETM+ & 90 \\
\hline Kavzoglu and Colkesen (2009) & Kocaeil, Turkey & 2002 & Aster & 88 \\
\hline Kavzoglu and Colkesen (2009) & Kocaeil, Turkey & 2002 & Aster & 93 \\
\hline Kavzoglu and Colkesen (2009) & Kocaeil, Turkey & 2002 & Aster & 91 \\
\hline Kavzoglu and Colkesen (2009) & Kocaeil, Turkey & 1997 & Landsat ETM+ & 87 \\
\hline Kaya et al. (2002) & Kenya & 2001 & RADARSAT-1 & 85 \\
\hline Keuchel et al. (2003) & Tenerife, Spain & 1988 & Landsat 5TM & 90 \\
\hline
\end{tabular}


Table C1. Continued.

\begin{tabular}{|c|c|c|c|c|}
\hline Source & Area & $\begin{array}{l}\text { Image } \\
\text { year }\end{array}$ & Image source & $\begin{array}{c}\text { Overall } \\
\text { accuracy } \\
(\%)\end{array}$ \\
\hline Keuchel et al. (2003) & Tenerife, Spain & 1988 & Landsat 5TM & 88 \\
\hline Keuchel et al. (2003) & Tenerife, Spain & 1988 & Landsat 5TM & 93 \\
\hline Klein et al. (2012) & Central Asia & 2009 & MODIS & 91 \\
\hline Kolios and Stylios (2013) & Greece & 2009 & Landsat 7 ETM+ & 97 \\
\hline Liu and Yang (2013) & Jilin, China & 2009 & Landsat TM & 95 \\
\hline Liu et al. (2002) & Rondonia, Brazil & $1995 / 1997$ & Landsat TM/Spot & 80 \\
\hline Mayaux et al. (2006) & Global & 1999-2000 & SPOT-Vegetation & 68 \\
\hline Munthali and Murayama (2011) & Dzalanyama, Malawi & 2008 & ALOS & 79 \\
\hline Munthali and Murayama (2011) & Dzalanyama, Malawi & 2000 & Landsat ETM+ & 78 \\
\hline Oldeland et al. (2010) & Rehoboth, Namibia & 2005 & HyMap & 98 \\
\hline Otukei and Blaschke (2010) & Pallisa, Uganda & 2001 & Landsat 7 ETM+ & 94 \\
\hline Pan et al. (2010) & $\begin{array}{l}\text { Honghe Reserve, } \\
\text { China }\end{array}$ & 2006 & Landsat-5 TM & 88 \\
\hline Peña-Barragán et al. (2011) & $\begin{array}{l}\text { Yolo County, } \\
\text { California }\end{array}$ & 2006 & ASTER & 79 \\
\hline Pérez-Hoyos et al. (2012) & Regional/Europe & - & $\begin{array}{l}\text { Merged-global } \\
\text { maps }\end{array}$ & 87 \\
\hline Petropoulos et al. (2012) & Greece & 2009 & Hyperion & 89 \\
\hline Qi et al. (2012) & Panyu, China & 2009 & $\begin{array}{l}\text { RADARSAT- } 2 \\
\text { PolSAR }\end{array}$ & 87 \\
\hline Ren et al. (2009) & NW Yunnan, China & 2000 & Landsat ETM+ & 97 \\
\hline Reno et al. (2011) & Amazon, Brazil & 2008 & Landsat 5 & 83 \\
\hline Renó et al. (2011) & Amazon, Brazil & 1970 & Landsat 2 & 86 \\
\hline $\begin{array}{l}\text { Rodriguez-Galiano and Chica- } \\
\text { Olmo (2012) }\end{array}$ & Granada, Spain & 2004 & Landsat 5TM & 86 \\
\hline Rozenstein and Karnieli (2011) & Israel & 2009 & Landsat $5 \mathrm{TM}$ & 81 \\
\hline Setiawan et al. (2006) & Yogyakarta, Indonesia & 1994 & Landsat TM & 80 \\
\hline Shao and Lunetta (2012) & $\begin{array}{l}\text { North Carolina and } \\
\text { Virginia, USA }\end{array}$ & 2000-2009 & MODIS & 91 \\
\hline Shimoni et al. (2009) & $\begin{array}{l}\text { Glinska Poljana, } \\
\text { Croatia }\end{array}$ & 2001 & E-SAR & 84 \\
\hline Shrestha and Zinck (2001) & Likhu Basin, Nepal & 1988 & Landsat TM & 94 \\
\hline Song et al. (2005) & Connecticut, USA & 2001 & Landsat ETM & 85 \\
\hline Stavrakoudis et al. (2011) & Lake Koronia, Greece & 2005 & IKONOS & 93 \\
\hline Stefanov et al. (2001) & Arizona, USA & 1998 & Landsat TM & 85 \\
\hline Sulla-Menashe et al. (2011) & $\begin{array}{l}\text { Regional/Northern } \\
\text { Eurasia }\end{array}$ & $2001-2005$ & MODIS & 73 \\
\hline
\end{tabular}


Table C1. Continued.

\begin{tabular}{|c|c|c|c|c|}
\hline Source & Area & $\begin{array}{l}\text { Image } \\
\text { year }\end{array}$ & Image source & $\begin{array}{c}\text { Overall } \\
\text { accuracy } \\
(\%)\end{array}$ \\
\hline Szuster et al. (2011) & Thai island, Thailand & 2004 & ASTER & 95 \\
\hline Szuster et al. (2011) & Thai island, Thailand & 2004 & ASTER & 94 \\
\hline Szuster et al. (2011) & Thai island, Thailand & 2004 & ASTER & 94 \\
\hline Taşdemir et al. (2012) & Bulgaria & 2009 & Rapideye & 94 \\
\hline Thenkabail et al. (2009a) & Global & 1997-1999 & AVHHR & 79 \\
\hline Tovar et al. (2013) & Cajamarca, Peru & 2007 & Landsat 5 TM & 80 \\
\hline Tseng et al. (2008) & Connecticut, USA & 1987 & Landsat TM & 98 \\
\hline Wang et al. (2010) & Hengshan, China & 2003 & Hyprion & 80 \\
\hline Waske and Braun (2009) & Jena, Germany & 2005 & ENVISAT/ERS-2 & 83 \\
\hline Weiers et al. (2002) & $\begin{array}{l}\text { Schleswig-Holstein, } \\
\text { Germany }\end{array}$ & 1992-1997 & Landsat TM & 85 \\
\hline Weiers et al. (2002) & Denmark & 1992-1997 & Landsat TM & 70 \\
\hline Whiteside et al. (2011) & $\begin{array}{l}\text { Florence Creek, } \\
\text { Australia }\end{array}$ & 2000 & ASTER & 79 \\
\hline Wickham et al. (2013) & USA & 2001 & Landsat TM & 79 \\
\hline Wickham et al. (2013) & USA & 2006 & Landsat TM & 78 \\
\hline Wickham et al. (2013) & USA & 2001 & Landsat TM & 85 \\
\hline Wickham et al. (2013) & USA & 2006 & Landsat TM & 84 \\
\hline Wu et al. (2010) & Dan-Shuei, China & 1995 & Landsat 5 TM & 88 \\
\hline Zhang et al. (2008) & $\begin{array}{l}\text { North China plain, } \\
\text { China }\end{array}$ & 2003 & MODIS_EVI & 75 \\
\hline Zhu et al. (2012) & Massachusetts, USA & 2007 & ALOS & 72 \\
\hline Zhu et al. (2012) & Massachusetts, USA & 2000-2007 & Landsat/ALOS & 94 \\
\hline Zhu et al. (2012) & Massachusetts, USA & 2000-2002 & Landsat & 93 \\
\hline
\end{tabular}




\section{Appendix D: Glossary}

Table D1. Glossary.

\begin{tabular}{|c|c|}
\hline Term & Description \\
\hline 1DD & One degree daily \\
\hline 3B42RT & $3 \mathrm{~B} 42$ real time \\
\hline ALEXI & Atmosphere-Land Exchange Inverse \\
\hline ALOS & Advanced Land Observing Satellite \\
\hline AMSR-E & Advanced Microwave Sounding Radiometer-Earth \\
\hline AMSU & Advanced Microwave Sounding Unit \\
\hline ASTER & Advanced Spaceborne Thermal Emission and Reflection Radiometer \\
\hline AVHRR & Advanced Very High Resolution Radiometer \\
\hline CBERS & China Brazil Earth Resources Satellite \\
\hline CMAP & CPC Merged Analysis of Precipitation \\
\hline CMORPH & CPC Morphing technique \\
\hline CMRSET & CSIRO MODIS Reflectance-based Scaling ET \\
\hline CORINE & Coordination of Information on the Environment \\
\hline $\mathrm{CPC}$ & Climate Prediction Center \\
\hline CSIRO & Commonwealth Science and Industrial Research Organisation \\
\hline DMSP & Defense Meteorological Satellite Program \\
\hline EARS & Environmental Analysis and Remote Sensing \\
\hline EUMETSAT & European Organisation for the Exploitation of Meteorological Satellites \\
\hline FEWS & Famine Early Warning Systems (FEWS) \\
\hline GOES & Geostationary Operational Environmental Satellites \\
\hline GPCC & Global Precipitation Climatology Centre \\
\hline GPCP & Global Precipitation Climatology Project \\
\hline GPI & GOES precipitation index \\
\hline GSFC & Goddard Space Flight Center (GSFC) \\
\hline GSMaP & Global Satellite Mapping of Precipitation \\
\hline HIRS & High-resolution Infrared Radiation Sounder \\
\hline IR & Infrared \\
\hline IWMI & International Water Management Institute \\
\hline METRIC & Mapping EvapoTranspiration at high Resolution with Internalized Calibration \\
\hline MODIS & Moderate Resolution Imaging Spectrometer \\
\hline MPE & Multi-Sensor Precipitation Estimate \\
\hline NASA & National Aeronautics and Space Administration \\
\hline NDTI & Normalized difference temperature index \\
\hline NOAA & National Oceanic and Atmospheric Administration \\
\hline PERSIANN & Precipitation Estimation From Remotely Sensed Information using Artificial Neural Networks \\
\hline PR & Precipitation radar \\
\hline RFE & Rainfall estimation algorithm \\
\hline SatDAET & Satellite daily ET \\
\hline SEBAL & Surface Energy Balance Algorithm for Land \\
\hline SEBS & Surface Energy Balance System \\
\hline SEEAW & System of Environmental-Economic Accounts for Water \\
\hline SPOT & Satellite Pour l'Observation de la Terre \\
\hline $\mathrm{SSM} / \mathrm{I}$ & Special Sensor Microwave/Imager \\
\hline TAMSAT & Tropical Applications of Meteorology using Satellite data \\
\hline TCI & TRMM Combined Instrument \\
\hline TMI & TRMM Microwave Imager \\
\hline TOVS & TIROS Operational Vertical Sounder \\
\hline TRMM & Tropical Rainfall Measuring Mission \\
\hline TSEB & Two source energy balance \\
\hline VIIRS & Visible Infrared Imager Radiometer Suite \\
\hline WIRADA & Water Information Research and Development Alliance \\
\hline
\end{tabular}


Acknowledgements. Funds for this research were provided by the CGIAR Research Programme on Water, Land and Ecosystems.

Edited by: B. van den Hurk

\section{References}

ABS - Australian Bureau of Statistics: Water Account, Australia 2000-01, Canberra, 2004.

Abd El-Kawy, O. R., Rød, J. K., Ismail, H. A., and Suliman, A. S.: Land use and land cover change detection in the western Nile delta of Egypt using remote sensing data, Appl. Geogr., 31, 483494, doi:10.1016/j.apgeog.2010.10.012, 2011.

Aguirre-Gutiérrez, J., Seijmonsbergen, A. C., and Duivenvoorden, J. F.: Optimizing land cover classification accuracy for change detection, a combined pixel-based and object-based approach in a mountainous area in Mexico, Appl. Geogr., 34, 29-37, doi:10.1016/j.apgeog.2011.10.010, 2012.

Allen, R. G., Pereira, L., Raes, D., and Smith, M.: Crop evapotranspiration: guidelines for computing crop water requirements, Issues 56-57, Food and Agriculture Organization of the United Nations, Rome, Italy, 1998.

Allen, R. G., Tasumi, M., Morse, A., and Trezza, R.: A Landsatbased energy balance and evapotranspiration model in Western US water rights regulation and planning, Irrig. Drain. Syst., 19, 251-268, doi:10.1007/s10795-005-5187-z, 2005.

Allen, R. G., Tasumi, M., Morse, A., Trezza, R., Wright, J. L., Bastiaanssen, W., Kramber, W., Lorite, I., and Robison, C. W.: Satellite-Based Energy Balance for Mapping Evapotranspiration with Internalized Calibration (METRIC) - Applications, J. Irrig. Drain. Eng., 133, 395-406, 2007.

Allen, R. G., Irmak, A., Trezza, R., Hendrickx, J. M. H., Bastiaanssen, W. and Kjaersgaard, J.: Satellite-based ET estimation in agriculture using SEBAL and METRIC, Hydrol. Process., 25, 4011-4027, doi:10.1002/hyp.8408, 2011.

Almazroui, M.: Calibration of TRMM rainfall climatology over Saudi Arabia during 1998-2009, Atmos. Res., 99, 400-414, 2011.

Almazroui, M., Islam, M. N., Jones, P. D., Athar, H., and Rahman, M. A.: Recent climate change in the Arabian Peninsula: Seasonal rainfall and temperature climatology of Saudi Arabia for 1979-2009, Atmos. Res., 111, 29-45, doi:10.1016/j.atmosres.2012.02.013, 2012.

Anderson, M. C., Norman, J. M., Diak, G. R., Kustas, W. P., and Mecikalski, J. R.: A Two-Source Time-Integrated Model for Estimating Surface Fluxes Using Thermal Infrared Remote Sensing, Remote Sens. Environ., 60, 195-216, doi:10.1016/S00344257(96)00215-5, 1997.

Anderson, M. C., Kustas, W. P., Norman, J. M., Hain, C. R., Mecikalski, J. R., Schultz, L., González-Dugo, M. P., Cammalleri, C., d'Urso, G., Pimstein, A., and Gao, F.: Mapping daily evapotranspiration at field to continental scales using geostationary and polar orbiting satellite imagery, Hydrol. Earth Syst. Sci., 15, 223-239, doi:10.5194/hess-15-223-2011, 2011.

Anderson, M. C., Kustas, W. P., Alfieri, J. G., Gao, F., Hain, C., Prueger, J. H., Evett, S., Colaizzi, P., Howell, T., and Chávez, J. L.: Mapping daily evapotranspiration at Landsat spatial scales during the BEAREX'08 field campaign, Adv. Water Resour., 50, 162-177, doi:10.1016/j.advwatres.2012.06.005, 2012.

Andre, J. C., Goutorbe, J. P., and Penier, A.: HAPEX-MOBILHY, a hydrologic atmospheric pilot experiment for the study of water budget and evaporation flux at the climatic scales, B. Am. Meteorol. Soc., 67, 138-144, 1986.

Asadullah, A., McIntyre, N. E. I. L., and Kigobe, M.: Evaluation of five satellite products for estimation of rainfall over Uganda, Hydrolog. Sci. J., 53, 1137-1150, 2008.

Asadullah, A., Mcintyre, N., and Kigobe, M. A. X.: Evaluation of five satellite products for estimation of rainfall over Uganda/Evaluation de cinq produits satellitaires pour l'estimation des précipitations en Ouganda Evaluation of five satellite products for estimation of rainfall over Uganda, Hydrolog. Sci. J., 53, 1137-1150, 2010.

Austin, P. M.: Relation between measured radar reflectivity and surface rainfall, Mon. Weather Rev., 115, 1053-1070, 1987.

Awulachew, S. B., Molden, D., Smakhtin, V., and Peden, D.: The Nile River Basin: Water, Agriculture, Governance and Livelihoods, Routledge, Oxon, UK, 2013.

Bach, M., Breuer, L., Frede, H. G., Huisman, J. A., Otte, A., and Waldhardt, R.: Accuracy and congruency of three different digital land-use maps, Landsc. Urban Plan., 78, 289-299, doi:10.1016/j.landurbplan.2005.09.004, 2006.

Barrett, E. C.: Precipitation monitoring by satellites. Remote sensing for studies of global environmental changes, ISPRA Courses, RS/88/10, Commission of European communities, Joint Research Center, Ispra Establishment, Ispra, Italy, 1988.

Barrett, E. C. and Beaumont, M. J.: Satellite rainfall monitoring: An overview, Remote Sens. Rev., 11, 23-48, doi:10.1080/02757259409532257, 1994.

Bastiaanssen, W. G. M.: Remote sensing in water resources management: the state of the art, International Water Management Institute (IWMI), Colombo, Sri Lanka, 1998.

Bastiaanssen, W. G. M. and Chandrapala, L.: Water balance variability across Sri Lanka for assessing agricultural and environmental water use, Agric. Water Manage., 58, 171-192, 2003.

Bastiaanssen, W. G. M., Menenti, M., Feddes, R. A., Holtslag, A. A. M., Pelgrum, H., Wang, J., Ma, Y., Moreno, J. F., Roerink, G. J., and van der Wal, T.: A remote sensing surface energy balance algorithm for land (SEBAL), 1. Formulation, J. Hydrol., 212213, 198-212, 1998.

Bastiaanssen, W. G. M., Molden, D. J., and Makin, I. W.: Remote sensing for irrigated agriculture: examples from research and possible applications, Agric. Water Manage., 46, 137-155, doi:10.1016/S0378-3774(00)00080-9, 2000.

Bastiaanssen, W. G. M., Ahmad, M.-D., and Chemin, Y.: Satellite surveillance of evaporative depletion across the Indus Basin, Water Resour. Res., 38, 9-1-9-9, doi:10.1029/2001WR000386, 2002.

Bastiaanssen, W. G. M., Miltenburg, I., Evans, R., Molloy, R., Bastiaanssen, F. J. M., and van der Pol, E.: An operational satellitebased irrigation monitoring and scheduling tool for saving water in irrigation, in Irrigation and Drainage Conference, Swan Hill, Vic, Australia, 2009.

Bastiaanssen, W. G. M., Cheema, M. J. M., Immerzeel, W. W., Miltenburg, I., and Pelgrum, H.: The surface energy balance and actual evapotranspiration of the transboundary Indus Basin estimated from satellite measurements and the ETLook model, 
Water Resour. Res., 48, W11512, doi:10.1029/2011WR010482, 2012.

Batra, N., Islam, S., Venturini, V., Bisht, G., and Jiang, L.: Estimation and comparison of evapotranspiration from MODIS and AVHRR sensors for clear sky days over the Southern Great Plains, Remote Sens. Environ., 103, 1-15, doi:10.1016/j.rse.2006.02.019, 2006.

Bicheron, P., Defourny, P., Brockmann, C., Schouten, L., Vancutsem, C., Huc, M., Bontemps, S., Leroy, M., Achard, F., Herold, M., Ranera, F., and Arino, O.: GLOBCOVER Products Report Description and Products Description and Validation Report, MEDIAS, France, 2008.

Bitew, M. M. and Gebremichael, M.: Evaluation of satellite rainfall products through hydrologic simulation in a fully distributed hydrologic model, Water Resour. Res., 47, W06526, doi:10.1029/2010WR009917, 2011.

Blanco, P. D., Colditz, R. R., López Saldaña, G., Hardtke, L. A., Llamas, R. M., Mari, N. A., Fischer, A., Caride, C., Aceñolaza, P. G., del Valle, H. F., Lillo-Saavedra, M., Coronato, F., Opazo, S. A., Morelli, F., Anaya, J. A., Sione, W. F., Zamboni, P., and Arroyo, V. B.: A land cover map of Latin America and the Caribbean in the framework of the SERENA project, Remote Sens. Environ., 132, 13-31, doi:10.1016/j.rse.2012.12.025, 2013.

Bolle, H. J., Eckardt, M., Koslowsky, D., Maselli, F., MeliaMiralles, J., Menenti, M., Olesen, F.-S., Petkov, L., Rasool, I., and van deGriend, A.: Mediterranean land-surface processes assessed from space, Series: Regional Climate Studies, XXVIII, Springer, Berlin, 760 pp., 2006.

Bosch, J. M. and Hewlett, J. D.: A review of catchment experiments to determine the effect of vegetation changes on water yield and evapotranspiration, J. Hydrol., 55, 3-23, doi:10.1016/00221694(82)90117-2, 1982.

Brutsaert, W.: Evaporation into the Atmosphere, Theory, History and Applications, D. Reidel Publishing Company, Dordrecht, the Netherlands, 302 pp., 1982.

Büttner, G., Feranec, J., and Jaffrain, G.: The thematic accuracy of Corine land cover 2000, European Environment Agency, Copenhagen, 2006.

Campbell, G. S. and Norman, J. M.: An introduction to environmental biophysics, Springer, New York, 1998.

Cassidy, L., Southworth, J., Gibbes, C., and Binford, M.: Beyond classifications: Combining continuous and discrete approaches to better understand land-cover change within the lower Mekong River region, Appl. Geogr., 39, 26-45, doi:10.1016/j.apgeog.2012.11.021, 2013.

Chartres, C. and Varma, S.: Out of Water: From Abundance to Scarcity and How to Solve the World's Water Problems, FT Press, New Jersey, 2010.

Chávez, J. L., Neale, C. M. U., Prueger, J. H., and Kustas, W. P.: Daily evapotranspiration estimates from extrapolating instantaneous airborne remote sensing ET values, Irrig. Sci., 27, 67-81, doi:10.1007/s00271-008-0122-3, 2008.

Cheema, M. J. M. and Bastiaanssen, W. G. M.: Land use and land cover classification in the irrigated Indus Basin using growth phenology information from satellite data to support water management analysis, Agric. Water Manage., 97, 1541-1552, 2010.

Cheema, M. J. M. and Bastiaanssen, W. G. M.: Local calibration of remotely sensed rainfall from the TRMM satellite for different periods and spatial scales in the Indus Basin, Int. J. Remote Sens., 33, 2603-2627, 2012.

Chehbouni, A., Kerr, Y. H., Watts, C., Hartogensis, O., Goodrich, D., Scott, R., Schieldge, J., Lee, K., Shuttleworth, W. J., Dedieu, G., and De Bruin, H. A. R.: Estimation of area-average sensible heat flux using a large-aperture scintillometer during the SemiArid Land-Surface-Atmosphere (SALSA) Experiment, Water Resour. Res., 35, 2505-2511, doi:10.1029/1999WR900111, 1999.

Chen, C., Yu, Z., Li, L., and Yang, C.: Adaptability Evaluation of TRMM Satellite Rainfall and Its Application in the Dongjiang River Basin, Proced. Environ. Sci., 10, 396-402, doi:10.1016/j.proenv.2011.09.065, 2011.

Choudhury, B. J.: Synergism of optical and microwave observations for land surface studies, in: Passive microwave remote sensing of land-atmosphere interactions, microwave remote sensing of land-atmosphere interactions, edited by: Choudhury, B. J., Kerr, Y. H., Njoku, E. G., and Pampaloni, P., VSP BV, Utrecht, the Netherlands, 155-191, 1995.

Cihlar, J.: Land cover mapping of large areas from satellites?: Status and research priorities, Int. J. Remote Sens., 21, 1093-1114, 2000.

Cingolani, A.: Mapping vegetation in a heterogeneous mountain rangeland using landsat data: an alternative method to define and classify land-cover units, Remote Sens. Environ., 92, 84-97, doi:10.1016/j.rse.2004.05.008, 2004.

Clark, M. L., Aide, T. M., Grau, H. R. and Riner, G.: A scalable approach to mapping annual land cover at $250 \mathrm{~m}$ using MODIS time series data: A case study in the Dry Chaco ecoregion of South America, Remote Sens. Environ., 114, 2816-2832, doi:10.1016/j.rse.2010.07.001, 2010.

Cleugh, H. A., Leuning, R., Mu, Q., and Running, S. W.: Regional evaporation estimates from flux tower and MODIS satellite data, Remote Sens. Environ., 106, 285-304, doi:10.1016/j.rse.2006.07.007, 2007.

Colditz, R. R., López Saldaña, G., Maeda, P., Espinoza, J. A., Tovar, C. M., Hernández, A. V., Benítez, C. Z., Cruz López, I., and Ressl, R.: Generation and analysis of the 2005 land cover map for Mexico using 250m MODIS data, Remote Sens. Environ., 123, 541-552, doi:10.1016/j.rse.2012.04.021, 2012.

Collischonn, B., Collischonn, W., and Tucci, C. E. M.: Daily hydrological modeling in the Amazon basin using TRMM rainfall estimates, J. Hydrol., 360, 207-216, doi:10.1016/j.jhydrol.2008.07.032, 2008.

Congalton, R. G.: A Review of Assessing the Accuracy of Classifications of Remotely Sensed Data, Remote Sens. Environ., 46, 35-46, 1991.

Courault, D., Seguin, B., and Olioso, A.: Review on estimation of evapotranspiration from remote sensing data: From empirical to numerical modeling approaches, Irrig. Drain. Syst., 19, 223-249, doi:10.1007/s10795-005-5186-0, 2005.

Cracknell, A. P. and Hayes, L.: Introduction to remote sensing, Taylor \& Francis, London, 1991.

Dee, D. P., Uppala, S. M., Simmons, A. J., Berrisford, P., Poli, P., Kobayashi, S., Andrae, U., Balmaseda, M. A., Balsamo, G., Bauer, P., Bechtold, P., Beljaars, A. C. M., van de Berg, L., Bidlot, J., Bormann, N., Delsol, C., Dragani, R., Fuentes, M., Geer, A. J., Haimberger, L., Healy, S. B., Hersbach, H., Hólm, E. V., Isaksen, L., Kållberg, P., Köhler, M., Matricardi, M., McNally, 
A. P., Monge-Sanz, B. M., Morcrette, J.-J., Park, B.-K., Peubey, C., de Rosnay, P., Tavolato, C., Thépaut, J.-N., and Vitart, F.: The ERA-Interim reanalysis: configuration and performance of the data assimilation system, Q. J. Roy. Meteorol. Soc., 137, 553597, doi:10.1002/qj.828, 2011.

Dinku, T., Ceccato, P., Grover-Kopec, E., Lemma, M., Connor, S. J., and Ropelewski, C. F.: Validation of satellite rainfall products over East Africa's complex topography, Int. J. Remote Sens., 28, 1503-1526, doi:10.1080/01431160600954688, 2007.

Dinku, T., Connor, S., and Ceccato, P.: Nile River Basin, in: Nile River Basin, edited by: Melesse, A. M., Springer Netherlands, Dordrecht, 109-127, 2011.

Duan, Z. and Bastiaanssen, W. G. M.: First results from Version 7 TRMM 3B43 precipitation product in combination with a new downscaling-calibration procedure, Remote Sens. Environ., 131, 1-13, doi:10.1016/j.rse.2012.12.002, 2013.

Dugdale, G. and Milford, J. R.: Rainfall estimation over the Sahel using Meteosat thermal infrared data, in: ISLSCP Parameterization of Land-Surface Characteristics: use of Satellite Data in Climate Studies, edited by: Rolfe, E. and Battrick, B., ESA, Paris, 315-319, 1986.

Dunne, S. C., Entekhabi, D., and Njoku, E.: Impact of multiresolution active and passive microwave measurements on soil moisture estimation using the Ensemble Kalman Smoother, IEEE T. Geosci. Remote, 45, 1016-1028, 2007.

Engman, E. T. and Gurney, R. J.: Remote sensing in hydrology, Chapman and Hall Ltd., London, 1991.

Estes, A. B., Kuemmerle, T., Kushnir, H., Radeloff, V. C., and Shugart, H. H.: Land-cover change and human population trends in the greater Serengeti ecosystem from 1984-2003, Biol. Conserv., 147, 255-263, doi:10.1016/j.biocon.2012.01.010, 2012.

Euser, T., Luxemburg, W. M. J., Everson, C. S., Mengistu, M. G., Clulow, A. D., and Bastiaanssen, W. G. M.: A new method to measure Bowen ratios using high-resolution vertical dry and wet bulb temperature profiles, Hydrol. Earth Syst. Sci., 18, 20212032, doi:10.5194/hess-18-2021-2014, 2014.

Evans, R., Bastiaanssen, W., Molloy, R., Hulbert, S., and Miltenburg, I.: Improving the picture for irrigation using SEBAL in Australia to measure evapotranspiration (ET), in: Irrigation and Drainage Conference 2009, Swan Hill, Vic, Australia, 2009.

Feidas, H.: Validation of satellite rainfall products over Greece, Theor. Appl. Climatol., 99, 193-216, doi:10.1007/s00704-0090135-8, 2009.

Fernandes, K., Fu, R., and Betts, A. K.: How well does the ERA40 surface water budget compare to observations in the Amazon River basin?, J. Geophys. Res., 113, D11117, doi:10.1029/2007JD009220, 2008.

Foody, G. M.: Status of land cover classification accuracy assessment, Remote Sens. Environ., 80, 185-201, doi:10.1016/S00344257(01)00295-4, 2002.

Franklin, S. E. and Wulder, M. A.: Remote sensing methods in medium spatial resolution satellite data land cover classification of large areas, Prog. Phys. Geogr., 26, 173-205, doi:10.1191/0309133302pp332ra, 2002.

Friedl, M. A., Sulla-Menashe, D., Tan, B., Schneider, A., Ramankutty, N., Sibley, A., and Huang, X.: MODIS Collection 5 global land cover: Algorithm refinements and characterization of new datasets, Remote Sens. Environ., 114(, 168-182, doi:10.1016/j.rse.2009.08.016, 2010.
Fu, Q., Ruan, R., and Liu, Y.: Accuracy Assessment of Global Satellite Mapping of Precipitation (GSMaP) Product over Poyang Lake Basin, China, Proced. Environ. Sci., 10, 2265-2271, doi:10.1016/j.proenv.2011.09.354, 2011.

Funk, C. C., Peterson, P. J., Landsfeld, M. F., Pedreros, D. H., Verdin, J. P., Rowland, J. D., Romero, B. E., Husak, G. J., Michaelsen, J. C., and Verdin, A. P.: A Quasi-Global Precipitation Time Series for Drought Monitoring, US Geological Survey Data Series 832, US Geological Survey, p. 4, doi:10.3133/ds832, 2013.

Gamanya, R., De Maeyer, P., and De Dapper, M.: An automated satellite image classification design using object-oriented segmentation algorithms: A move towards standardization, Expert Syst. Appl., 32, 616-624, doi:10.1016/j.eswa.2006.01.055, 2007.

García-Mora, T. J., Mas, J.-F., and Hinkley, E. A.: Land cover mapping applications with MODIS: a literature review, Int. J. Digit. Earth, 5, 63-87, doi:10.1080/17538947.2011.565080, 2012.

Getirana, A. C. V., Espinoza, J. C. V., Ronchail, J., and Rotunno Filho, O. C.: Assessment of different precipitation datasets and their impacts on the water balance of the Negro River basin, J. Hydrol., 404, 304-322, doi:10.1016/j.jhydrol.2011.04.037, 2011.

Glenn, E. P., Huete, A. R., Nagler, P. L., Hirschboeck, K. K., and Brown, P.: Integrating Remote Sensing and Ground Methods to Estimate Evapotranspiration, CRC, Crit. Rev. Plant Sci., 26, 139-168, doi:10.1080/07352680701402503, 2007.

Glenn, E. P., Doody, T. M., Guerschman, J. P., Huete, A. R., King, E. A., McVicar, T. R., Van Dijk, A. I. J. M., Van Niel, T. G., Yebra, M., and Zhang, Y.: Actual evapotranspiration estimation by ground and remote sensing methods: the Australian experience, Hydrol. Process., 25, 4103-4116, doi:10.1002/hyp.8391, 2011.

Gong, P., Wang, J., Yu, L., Zhao, Y. C., Zhao, Y. Y., Liang, L., Niu, Z. G., Huang, X. M., Fu, H. H., Liu, S., Li, C. C., Li, X. Y., Fu, W., Liu, C. X., Xu, Y., Wang, X. Y., Cheng, Q., Hu, L. Y., Yao, W. B., Zhang, H., Zhu, P., Zhao, Z. Y., Zhang, H. Y., Zheng, Y. M., Ji, L. Y., Zhang, Y. W., Chen, H., Yan, A., Guo, J. H., Yu, L., Wang, L., Liu, X. J., Shi, T. T., Zhu, M. H., Chen, Y. L., Yang, G. W., Tang, P., Xu, B., Ciri, C., Clinton, N., Zhu, Z. L., Chen, J., and Chen, J.: Finer resolution observation and monitoring of global land cover: first mapping results with Landsat TM and ETM+ data, Int. J. Remote Sens., 34, 2607-2654, 2013.

Gonzalez-Dugo, M. P., Neale, C. M. U., Mateos, L., Kustas, W. P., Prueger, J. H., Anderson, M. C., and Li, F.: A comparison of operational remote sensing-based models for estimating crop evapotranspiration, Agr. Forest Meteorol., 149, 1843-1853, doi:10.1016/j.agrformet.2009.06.012, 2009.

Goutorbe, J. P., Lebel, T., Dolman, A. J., Gash, J. H. C., Kabat, P., Kerr, Y. H., Monteny, B., Prince, S. D., Stricker, J. N. M., Tinga, A., and Wallace, J. S.: An overview of HAPEX-Sahel: a study in climate and desertification, J. Hydrol., 188-189, 4-17, doi:10.1016/S0022-1694(96)03308-2, 1997.

Gowda, P. H., Colaizzi, P. D., Evett, S. R., Howell, T. A., and Tolk, J. A.: Remote sensing based energy balance algorithms for mapping ET: current status and future challenges, T. ASABE, 50, 1639-1644, 2007

Groeneveld, D. P., Baugh, W. M., Sanderson, J. S., and Cooper, D. J.: Annual groundwater evapotranspiration mapped 
from single satellite scenes, J. Hydrol., 344, 146-156, doi:10.1016/j.jhydrol.2007.07.002, 2007.

Guerschman, J. P., Van Dijk, A. I. J. M., Mattersdorf, G., Beringer, J., Hutley, L. B., Leuning, R., Pipunic, R. C., and Sherman, B. S.: Scaling of potential evapotranspiration with MODIS data reproduces flux observations and catchment water balance observations across Australia, J. Hydrol., 369, 107-119, doi:10.1016/j.jhydrol.2009.02.013, 2009.

Hafeez, M. M., Chemin, Y., Van De Giesen, N., and Bouman, B. A. M.: Estimation of crop water deficit through remote sensing in Central Luzon, Philippines, in: vol. 5, IEEE International Geoscience and Remote Sensing Symposium, 24-28 June, Torento, Canada, 2778-2780, 2002.

Hartogensis, O. K., Weisensee, U., Evans, J., van Kesteren, A. J. H., and Beyrich, F.: First Results of two Optical Millimeterwave Scintillometer Systems during LITFASS2009, 10th EMS Annu. Meet. 10th Eur. Conf. Appl. Meteorol. Abstr., held: 13-17 September 2010, Zürich, Switzerland, http://meetings. copernicus.org/ems2010/ (last access: 5 October 2013), 2010.

Hemakumara, H. M. and Chandrapala, L.: Evapotranspiration fluxes over mixed vegetation areas measured from large aperture scintillometer, Agr. Water Manage., 58, 109-122, 2003.

Houser, P. R., Shuttleworth, W. J., Famiglietti, J. S., and Goodrich, D. C.: Integration of soil moisture remote sensing and hydrologic modeling using data assimilation, Water Resour. Res., 34, 34053420, 1998.

Hubert-Moy, L., Cotonnec, A., Le Du, L., Chardin, A., and Perez, P.: A comparison of parametric classification procedures of remotely sensed data applied on different landscape units, Remote Sens. Environ., 75, 174-187, 2001.

Huffman, G. J., Bolvin, D. T., Nelkin, E. J., Wolff, D. B., Adler, R. F., Gu, G., Hong, Y., Bowman, K. P., and Stocker, E. F.: The TRMM Multisatellite Precipitation Analysis (TMPA): Quasi-Global, Multiyear, Combined-Sensor Precipitation Estimates at Fine Scales, J. Hydrometeorol., 8, 38-55, doi:10.1175/JHM560.1, 2007.

Hunink, J. E., Immerzeel, W. W., and Droogers, P.: A High-resolution Precipitation 2-step mapping Procedure (HiP2P): Development and application to a tropical mountainous area, Remote Sens. Environ., 140, 179-188, doi:10.1016/j.rse.2013.08.036, 2014.

Immerzeel, W. W. and Droogers, P.: Calibration of a distributed hydrological model based on satellite evapotranspiration, J. Hydrol., 349, 411-424, doi:10.1016/j.jhydrol.2007.11.017, 2008.

Irmak, A. (Ed.): Evapotranspiration Remote Sensing and Modeling, InTech, Rijeka, Croatia, 2012.

Irmak, A., Ratcliffe, I., and Hubbard, K.: Estimation of Land Surface Evapotranspiration with a Satellite Remote Sensing Procedure, Great Plains Research 21, University of Nebraska, Lincoln, 73-88, 2011.

Jackson, T. J., Le Vine, D. M., Griffis, A. J., Goodrich, D. C., Schmugge, T. J., Swift, C. T., and O’Neill, P. E.: Soil moisture and rainfall estimation over a semiarid environment with the ESTAR microwave radiometer, IEEE T. Geosci. Remote, 31, 836841, doi:10.1109/36.239906, 1993.

Jarmain, C., Klaasse, A., Bastiaanssen, W. G. M., and Roux, A. S.: Remote sensing tools for water use efficiency of grapes in the Winelands region, Western Cape, in: 13th Sanciahs symposium, Cape Town, 2007.
Jarmain, C., Everson, C., Savage, M., Mengisto, M., Clulow, A., Walker, S., and Gush, M.: Refining tools for evaporation monitoring in support of water resources management, Water Research Commission, Pretoria, South Africa, 2009.

Jhorar, R. K., Smit, A. A. M. F. R., Bastiaanssen, W. G. M., and Roest, C. W. J.: Calibration of a distributed irrigation water management model using remotely sensed evapotranspiration rates and groundwater heads, Irrig. Drain., 60, 57-69, doi:10.1002/ird.541, 2011.

Jia, L., Su, B., van den Hurk, B., Menenti, M., Moene, A., and de Bruin, H. A. R.: Estimation of sensible heat flux using the Surface Energy Balance System (SEBS) and ATSR measurements, Phys. Chem. Earth, 28, 75-88, 2003.

Jia, Z., Liu, S., Xu, Z., Chen, Y., and Zhu, M.: Validation of remotely sensed evapotranspiration over the Hai River Basin, China, J. Geophys. Res., 117, D13113, doi:10.1029/2011JD017037, 2012.

Jiang, L., Islam, S., Guo, W., Singh Jutla, A., Senarath, S. U. S., Ramsay, B. H., and Eltahir, E.: A satellitebased Daily Actual Evapotranspiration estimation algorithm over South Florida, Global Planet. Change, 67, 62-77, doi:10.1016/j.gloplacha.2008.12.008, 2009.

Jiang, S., Ren, L., Hong, Y., Yong, B., Yang, X., Yuan, F., and Ma, M.: Comprehensive evaluation of multi-satellite precipitation products with a dense rain gauge network and optimally merging their simulated hydrological flows using the Bayesian model averaging method, J. Hydrol., 452-453, 213225, doi:10.1016/j.jhydrol.2012.05.055, 2012.

Kalma, J. D., McVicar, T. R., and McCabe, M. F.: Estimating land surface evaporation: A review of methods using remotely sensed surface temperature data, Surv. Geophys., 29, 421-469, 2008.

Kandrika, S. and Roy, P. S.: Land use land cover classification of Orissa using multi-temporal IRS-P6 awifs data: A decision tree approach, Int. J. Appl. Earth Obs. Geoinf., 10, 186-193, doi:10.1016/j.jag.2007.10.003, 2008.

Karimi, P., Bastiaanssen, W. G. M., and Molden, D.: Water Accounting Plus $(\mathrm{WA}+)$ - a water accounting procedure for complex river basins based on satellite measurements, Hydrol. Earth Syst. Sci., 17, 2459-2472, doi:10.5194/hess-17-24592013, 2013a.

Karimi, P., Bastiaanssen, W. G. M., Molden, D., and Cheema, M. J. M.: Basin-wide water accounting based on remote sensing data: an application for the Indus Basin, Hydrol. Earth Syst. Sci., 17, 2473-2486, doi:10.5194/hess-17-2473-2013, 2013b.

Karimi, P., Bastiaanssen, W. G. M., Sood, A., Hoogeveen, J., Peiser, L., Bastidas-Obando, E., and Dost, R.: Spatial evapotranspiration, rainfall and land use data in water accounting Part 2: Reliability of water accounting results for policy decisions in the Awash basin, Hydrol. Earth Syst. Sci., 19, 533-550, doi:10.5194/hess-19-533-2015, 2015.

Kavzoglu, T. and Colkesen, I.: A kernel functions analysis for support vector machines for land cover classification, Int. J. Appl. Earth Obs. Geoinf., 11, 352-359, doi:10.1016/j.jag.2009.06.002, 2009.

Kaya, S., Pultz, T. J., Mbogo, C. M., Beier, J. C., and Mushinzimana, E.: The Use of Radar Remote Sensing for Identifying Environmental Factors Associated with Malaria Risk in Coastal Kenya, International Geoscience and Remote Sensing Symposium (IGARSS '02), 24-28 June, Toronto, 2002. 
Keuchel, J., Naumann, S., Heiler, M., and Siegmund, A.: Automatic land cover analysis for Tenerife by supervised classification using remotely sensed data, Remote Sens. Environ., 86, 530-541, doi:10.1016/S0034-4257(03)00130-5, 2003.

Kidd, C.: Satellite rainfall climatology: a review, Int. J. Climatol., 21, 1041-1066, doi:10.1002/joc.635, 2001.

King, E. A., Van Niel, T. G., Van Dijk, A. I. J. M., Wang, Z., Paget, M. J., Raupach, T., Guerschman, J., Haverd, V., Mcvicar, T. R., Miltenburg, I., Raupach, M. R., and Zhang, Y.: Actual Evapotranspiration Estimates for Australia Inter-comparison and Evaluation, CSIRO: Water for a Healthy Country National Research Flagship Copyright, Canberra, 2011.

Kiptala, J., Mohamed, Y., Mul, M., Cheema, M. J. M., and van der Zaag, P.: Land use and land cover classification using phenological variability from MODIS vegetation in the Upper Pangani River Basin, Eastern Africa, Phys. Chem. Earth A/B/C, 66, 112122, 2013.

Kite, G. and Droogers, P.: Comparing evapotranspiration estimates from satellites, hydrological models and field data, J. Hydrol., 229, 1-2, doi:10.1016/S0022-1694(99)00193-6, 2000.

Kizza, M., Westerberg, I., Rodhe, A., and Ntale, H. K.: Estimating areal rainfall over Lake Victoria and its basin using ground-based and satellite data, J. Hydrol., 464-465, 401-411, doi:10.1016/j.jhydrol.2012.07.024, 2012.

Klein, I., Gessner, U., and Kuenzer, C.: Regional land cover mapping and change detection in Central Asia using MODIS time-series, Appl. Geogr., 35, 219-234, doi:10.1016/j.apgeog.2012.06.016, 2012.

Kolios, S. and Stylios, C. D.: Identification of land cover/land use changes in the greater area of the Preveza peninsula in Greece using Landsat satellite data, Appl. Geogr., 40, 150-160, doi:10.1016/j.apgeog.2013.02.005, 2013.

Kummerow, C., Olson, W. S., and Giglio, L.: A simplified scheme for obtaining precipitation and vertical hydrometeor profiles from passive microwave sensors, IEEE T. Geosci. Remote, 34, 1213-1232, doi:10.1109/36.536538, 1996.

Kustas, W. P. and Norman, J. M.: Use of remote sensing for evapotranspiration monitoring over land surfaces, Hydrolog. Sci. J., 41, 495-516, doi:10.1080/02626669609491522, 1996.

Kustas, W. P., Anderson, M. C., French, A. N., and Vickers, D.: Using a remote sensing field experiment to investigate fluxfootprint relations and flux sampling distributions for tower and aircraft-based observations, Adv. Water Resour., 29, 355-368, doi:10.1016/j.advwatres.2005.05.003, 2006.

Lal, D., Clark, B., Bettner, T., Thoreson, B., and Snyder, R.: Rice evapotranspiration estimates and crop coefficients in GlennColusa Irrigation District, Sacramento Valley, California, in: USCID Water Management Conference, Austin, 2012.

Li, H., Wang, H., Kong, Y., and Li, L.: Estimation of evapotranspiration in Yellow River Delta wetland based on two-source energy balance (TSEB) model, Remote Sensing Technol. Appl., 27, 5867, 2012.

Liu, T. and Yang, X.: Mapping vegetation in an urban area with stratified classification and multiple endmember spectral mixture analysis, Remote Sens. Environ., 133, 251-264, doi:10.1016/j.rse.2013.02.020, 2013.

Liu, X.-H., Skidmore, A. K., and Van Oosten, H.: Integration of classification methods for improvement of land-cover map accuracy, ISPRS J. Photogramm. Remote Sens., 56, 257-268, doi:10.1016/S0924-2716(02)00061-8, 2002.

Ma, W., Hafeez, M., Rabbani, U., Ishikawa, H., and Ma, Y.: Retrieved actual ET using SEBS model from Landsat-5 TM data for irrigation area of Australia, Atmos. Environ., 59, 408-414, doi:10.1016/j.atmosenv.2012.05.040, 2012.

Maes, W. H., Heuvelmans, G., and Muys, B.: Assessment of Land Use Impact on Water-Related Ecosystem Services Capturing the Integrated Terrestrial-Aquatic System, Environ. Sci. Technol., 43, 7324-7330, doi:10.1021/es900613w, 2009.

Mallick, K., Bhattacharya, B. K., Chaurasia, S., Dutta, S., Nigam, R., Mukherjee, J., Banerjee, S., Kar, G., Rao, V. U. M., Gadgil, A. S., and Parihar, J. S.: Evapotranspiration using MODIS data and limited ground observations over selected agroecosystems in India, Int. J. Remote Sens., 28, 2091-2110, 2007.

Mayaux, P., Eva, H., Gallego, J., Strahler, A. H. A. H., Herold, M., Agrawal, S., Naumov, S., De Miranda, E. E., Di Bella, C. M., Ordoyne, C., Kopin, Y., Roy, P. S. S., Member, S., De Miranda, E. E., and Di Bella, C. M.: Validation of the global land cover 2000 map, IEEE T. Geosci. Remote, 44, 1728-1739, doi:10.1109/TGRS.2006.864370, 2006.

Mcvicar, T. R. and Jupp, D. L. B.: Estimating one-time-of-day meteorological data from standard daily data as inputs to thermal remote sensing based energy balance models, Agr. Forest Meteorol., 96, 219-238, 1999.

Mcvicar, T. R. and Jupp, D. L. B.: Using covariates to spatially interpolate moisture availability in the Murray - Darling Basin A novel use of remotely sensed data, Remote Sens. Environ., 79, 199-212, 2002.

Meijninger, W. M. L. and de Bruin, H. A. R.: The sensible heat fluxes over irrigated areas in western Turkey determined with a large aperture scintillometer, J. Hydrol., 229, 42-49, doi:10.1016/S0022-1694(99)00197-3, 2000.

Milewski, A., Sultan, M., Jayaprakash, S. M., Balekai, R., and Becker, R.: RESDEM, a tool for integrating temporal remote sensing data for use in hydrogeologic investigations, Comput. Geosci., 35, 2001-2010, doi:10.1016/j.cageo.2009.02.010, 2009.

Miralles, D. G., Holmes, T. R. H., De Jeu, R. A. M., Gash, J. H., Meesters, A. G. C. A., and Dolman, A. J.: Global land-surface evaporation estimated from satellite-based observations, Hydrol. Earth Syst. Sci., 15, 453-469, doi:10.5194/hess-15-453-2011, 2011.

Moffitt, C. B., Hossain, F., Adler, R. F., Yilmaz, K. K., and Pierce, H. F.: Validation of a TRMM-based global Flood Detection System in Bangladesh, Int. J. Appl. Earth Obs. Geoinf., 13, 165-177, doi:10.1016/j.jag.2010.11.003, 2011.

Mohamed, Y. A., Bastiaanssen, W. G. M., and Savenije, H. H. G.: Spatial variability of evaporation and moisture storage in the swamps of the upper Nile studied by remote sensing techniques, J. Hydrol., 289, 145-164, doi:10.1016/j.jhydrol.2003.11.038, 2004.

Molden, D.: Water for food, water for life: A comprehensive assessment of water management in agriculture, Earthscan, London, 2007.

Molden, D., Dong, B., Loeve, R., Barker, R., and Tuong, T. P.: Agricultural water productivity and savings: policy lessons from two diverse sites in China, Water Policy, 9, 29-44, 2007.

Moon, B., Hong, J., Lee, B., Yun, J. I., Park, E. W., and Kim, J.: $\mathrm{CO}_{2}$ and energy exchange in a rice paddy for the growing sea- 
son of 2002 in Hari, Korea Byung-Kwan, Korean J. Agric. For. Meteorol., 5, 51-60, 2003.

Moran, M. S. and Jackson, R. D.: Assessing the spatial distribution of evapotranspiration using remotely sensed inputs, J. Environ. Qual., 20, 725-737, 1991.

Moran, M. S., Clarke, T. R., Inoue, Y., and Vidal, A.: Estimating crop water deficit using the relation between surface-air temperature and spectral vegetation index, Remote Sens. Environ., 49, 246-263, doi:10.1016/0034-4257(94)90020-5, 1994.

Mu, Q., Heinsch, F. A., Zhao, M., and Running, S. W.: Development of a global evapotranspiration algorithm based on MODIS and global meteorology data, Remote Sens. Environ., 111, 519-536, 2007.

Mu, Q., Zhao, M., and Running, S. W.: Improvements to a MODIS global terrestrial evapotranspiration algorithm, Remote Sens. Environ., 115, 1781-1800, doi:10.1016/j.rse.2011.02.019, 2011.

Mucher, C. A., Steinnocher, K. T., Kressler, F. P., and Heunks, C.: Land cover characterization and change detection for environmental monitoring of pan-Europe, Int. J. Remote Sens., 21, 1159-1181, doi:10.1080/014311600210128, 2000.

Mueller, B., Hirschi, M., Jimenez, C., Ciais, P., Dirmeyer, P. A., Dolman, A. J., Fisher, J. B., Jung, M., Ludwig, F., Maignan, F., Miralles, D. G., McCabe, M. F., Reichstein, M., Sheffield, J., Wang, K., Wood, E. F., Zhang, Y., and Seneviratne, S. I.: Benchmark products for land evapotranspiration: LandFluxEVAL multi-data set synthesis, Hydrol. Earth Syst. Sci., 17, 3707-3720, doi:10.5194/hess-17-3707-2013, 2013.

Munthali, K. G. and Murayama, Y.: Land use/cover change detection and analysis for Dzalanyama forest reserve, Lilongwe, Malawi, Procedia - Social and Behavioral Sciences, 21, 203211, doi:10.1016/j.sbspro.2011.07.035, 2011.

Neale, C. M. U. and Cosh, M. H.: Remote sensing and hydrology, IAHS Red Book Series, Publ. 352, IAHS Wallingford, UK, 482 pp., 2012.

Nemani, R. R. and Running, S. W.: Estimation of Regional Surface Resistance to Evapotranspiration from NDVI and Thermal-IR AVHRR Data, J. Appl. Meteorol., 28, 276-284, doi:10.1175/1520-0450(1989)028<0276:EORSRT>2.0.CO;2, 1989.

Norman, J. M., Kustas, W. P., and Humes, K. S.: Source approach for estimating soil and vegetation energy fluxes in observations of directional radiometric surface temperature, Agr. Forest Meteorol., 77, 263-293, doi:10.1016/0168-1923(95)02265-Y, 1995.

Oldeland, J., Dorigo, W., Lieckfeld, L., Lucieer, A., and Jürgens, N.: Combining vegetation indices, constrained ordination and fuzzy classification for mapping semi-natural vegetation units from hyperspectral imagery, Remote Sens. Environ., 114, 1155-1166, doi:10.1016/j.rse.2010.01.003, 2010.

Otter, L. B., Guenther, A., and Greenberg, J.: Seasonal and spatial variations in biogenic hydrocarbon emissions from southern African savannas and woodlands, Atmos. Environ., 36, 42654275, 2002.

Otukei, J. R. and Blaschke, T.: Land cover change assessment using decision trees, support vector machines and maximum likelihood classification algorithms, Int. J. Appl. Earth Obs. Geoinf., 12, S27-S31, doi:10.1016/j.jag.2009.11.002, 2010.

Pan, X., Zhang, S., Zhang, H., Na, X., and Li, X.: A variable precision rough set approach to the remote sensing land use/cover classification, Comput. Geosci., 36, 1466-1473, doi:10.1016/j.cageo.2009.11.010, 2010.

Peña-Barragán, J. M., Ngugi, M. K., Plant, R. E., and Six, J.: Object-based crop identification using multiple vegetation indices, textural features and crop phenology, Remote Sens. Environ., 115, 1301-1316, doi:10.1016/j.rse.2011.01.009, 2011.

Pérez-Hoyos, A., García-Haro, F. J., and San-Miguel-Ayanz, J.: A methodology to generate a synergetic land-cover map by fusion of different land-cover products, Int. J. Appl. Earth Obs. Geoinf., 19, 72-87, doi:10.1016/j.jag.2012.04.011, 2012.

Petropoulos, G. P., Kalaitzidis, C., and Prasad Vadrevu, K.: Support vector machines and object-based classification for obtaining land-use/cover cartography from Hyperion hyperspectral imagery, Comput. Geosci., 41, 99-107, doi:10.1016/j.cageo.2011.08.019, 2012.

Petty, G. W.: The status of satellite-based rainfall estimation over land, Remote Sens. Environ., 51, 125-137, doi:10.1016/00344257(94)00070-4, 1995.

Petty, G. W. and Krajewski, W. F. W. F.: Satellite estimation of precipitation over land, Hydrolog. Sci. J., 41, 433-452, doi:10.1080/02626669609491519, 1996.

Pierre, C., Bergametti, G., Marticorena, B., Mougin, E., Lebel, T., and Ali, A.: Pluriannual comparisons of satellite-based rainfall products over the Sahelian belt for seasonal vegetation modeling, J. Geophys. Res., 116, D18201, doi:10.1029/2011JD016115, 2011.

Qi, Z., Yeh, A. G.-O., Li, X., and Lin, Z.: A novel algorithm for land use and land cover classification using RADARSAT2 polarimetric SAR data, Remote Sens. Environ., 118, 21-39, doi:10.1016/j.rse.2011.11.001, 2012.

Rana, G. and Katerji, N.: Measurement and estimation of actual evapotranspiration in the field under Mediterranean climate: a review, Eur. J. Agron., 13, 125-153, doi:10.1016/S11610301(00)00070-8, 2000.

Rango, A., Ritchie, J. C., Kustas, W. P., Schmugge, T. J., Humes, K. S., Hipps, L. E., Prueger, J. H., and HavstadRango, K. M.: JORNEX: A multidisciplinary remote sensing campaign to quantify plant community/atmospheric interactions in the northern Chihuahuan desert of New Mexico, in: Hydrology in a Changing Environment, edited by: Wheater, H. and Kirby, C., John Wiley, London, UK, 585-590, 1998.

Ren, G., Zhu, A.-X., Wang, W., Xiao, W., Huang, Y., Li, G., Li, D., and Zhu, J.: A hierarchical approach coupled with coarse DEM information for improving the efficiency and accuracy of forest mapping over very rugged terrains, Forest Ecol. Manage., 258, 26-34, doi:10.1016/j.foreco.2009.03.043, 2009.

Renó, V. F., Novo, E. M. L. M., Suemitsu, C., Rennó, C. D., and Silva, T. S. F.: Assessment of deforestation in the Lower Amazon floodplain using historical Landsat MSS/TM imagery, Remote Sens. Environ., 115, 3446-3456, doi:10.1016/j.rse.2011.08.008, 2011.

Rientjes, T. H. M., Muthuwatta, L. P., Bos, M. G., Booij, M. J., and Bhatti, H. A.: Multi-variable calibration of a semi-distributed hydrological model using streamflow data and satellite-based evapotranspiration, J. Hydrol., 505, 276-290, 2013.

Rodriguez-Galiano, V. and Chica-Olmo, M.: Land cover change analysis of a Mediterranean area in Spain using different sources of data: Multi-seasonal Landsat images, land surface tempera- 
ture, digital terrain models and texture, Appl. Geogr., 35, 208218, doi:10.1016/j.apgeog.2012.06.014, 2012.

Roerink, G. J., Su, Z., and Menenti, M.: S-SEBI: A simple remote sensing algorithm to estimate the surface energy balance, Phys. Chem. Earth B, 25, 147-157, doi:10.1016/S14641909(99)00128-8, 2000.

Roerink, G. J., Menenti, M., Soepboer, W., and Su, Z.: Assessment of climate impact on vegetation dynamics by using remote sensing, Phys. Chem. Earth, A/B/C, 28, 103-109, doi:10.1016/S1474-7065(03)00011-1, 2003.

Rosema, A.: Comparison of Meteosat-based rainfall and evapotranspiration mapping in the Sahel region, Int. J. Remote Sens., 11, 2299-2309, doi:10.1080/01431169008955176, 1990.

Rozenstein, O. and Karnieli, A.: Comparison of methods for landuse classification incorporating remote sensing and GIS inputs, Appl. Geogr., 31, 533-544, doi:10.1016/j.apgeog.2010.11.006, 2011.

Schuurmans, J. M., Troch, P. A., Veldhuizen, A. A., Bastiaanssen, W. G. M., and Bierkens, M. F. P.: Assimilation of remotely sensed latent heat flux in a distributed hydrological model, Adv. Water Resour., 26, 151-159, 2003.

Scott, C. A., Bastiaanssen, W. G. M., and Ahmad, M.D.: Mapping Root Zone Soil Moisture Using Remotely Sensed Optical Imagery, J. Irrig. Drain. Eng., 129, 326-335, doi:10.1061/(ASCE)0733-9437(2003)129:5(326), 2003.

Semire, F. A., Mohd-Mokhtar, R., Ismail, W., Mohamad, N., and Mandeep, J. S. S.: Ground validation of space-borne satellite rainfall products in Malaysia, Adv. Space Res., 50, 1241-1249, doi:10.1016/j.asr.2012.06.031, 2012.

Setiawan, H., Mathieu, R., and Thompson-Fawcett, M.: Assessing the applicability of the V-I-S model to map urban land use in the developing world: Case study of Yogyakarta, Indonesia, Comput. Environ. Urban Syst., 30, 503522, doi:10.1016/j.compenvurbsys.2005.04.003, 2006.

Shao, Y. and Lunetta, R. S.: Comparison of support vector machine, neural network, and CART algorithms for the land-cover classification using limited training data points, ISPRS J. Photogramm. Remote Sens., 70, 78-87, doi:10.1016/j.isprsjprs.2012.04.001, 2012.

Shimoni, M., Borghys, D., Heremans, R., Perneel, C., and Acheroy, M.: Fusion of PolSAR and PolInSAR data for land cover classification, Int. J. Appl. Earth Obs. Geoinf., 11, 169-180, doi:10.1016/j.jag.2009.01.004, 2009.

Shrestha, D. P. and Zinck, J. A.: Land use classification in mountainous areas: integration of image processing, digital elevation data and field knowledge (application to Nepal), Int. J. Appl. Earth Obs. Geoinf., 3, 78-85, doi:10.1016/S0303-2434(01)85024-8, 2001.

Singh, R. K., Irmak, A., Irmak, S., and Martin, D. L.: Application of SEBAL Model for Mapping Evapotranspiration and Estimating Surface Energy Fluxes in South-Central Nebraska, J. Irrig. Drain. Eng., 134, 273-285, doi:10.1061/(ASCE)07339437(2008)134:3(273), 2008.

Singh, R. K., Liu, S., Tieszen, L. L., Suyker, A. E., and Verma, S. B.: Estimating seasonal evapotranspiration from temporal satellite images, Irrig. Sci., 30, 303-313, doi:10.1007/s00271-011-0287z, 2011.
Smith, D. M., Kniveton, D. R., and Barrett, E. C.: A Statistical Modeling Approach to Passive Microwave Rainfall Retrieval, J. Appl. Meteorol., 37, 135-154, 1998.

Smith, E. A., Cooper, H. J., Xiang, X., Mugnai, A., and Tripoli, G. J.: Foundations for Statistical-Physical Precipitation Retrieval from Passive Microwave Satellite Measurements. Part I: Brightness-Temperature Properties of a Time-dependent Cloud-Radiation Model, J. Appl. Meteorol., 31, 506-531, doi:10.1175/1520-0450(1992)031<0506:FFSPPR>2.0.CO;2, 1992.

Smits, P. C., Dellepiane, S. G., and Schowengerdt, R. a.: Quality assessment of image classification algorithms for land-cover mapping: A review and a proposal for a cost-based approach, Int. J. Remote Sens., 20, 1461-1486, doi:10.1080/014311699212560, 1999.

Song, M., Civco, D. L., and Hurd, J. D.: A competitive pixel-object approach for land cover classification, Int. J. Remote Sens., 26, 4981-4997, doi:10.1080/01431160500213912, 2005.

Soppe, R. W., Bastiaanssen, W., Keller, A., Clark, B., Thoreson, B., Eckhardt, J. and Davids, G.: Use of High Resolution Thermal Landsat Data to Estimate Evapotranspiration Within the Imperial Irrigation District in Southern California, Am. Geophys. Union, 2006.

Stavrakoudis, D. G., Theocharis, J. B., and Zalidis, G. C.: A Boosted Genetic Fuzzy Classifier for land cover classification of remote sensing imagery, ISPRS J. Photogramm. Remote Sens., 66, 529544, doi:10.1016/j.isprsjprs.2011.01.010, 2011.

Stefanov, W. L., Ramsey, M. S., and Christensen, P. R.: Monitoring urban land cover change?: An expert system approach to land cover classification of semiarid to arid urban centers, Remote Sens. Environ., 77, 173-185, 2001.

Stephens, G. L. and Kummerow, C. D.: The Remote Sensing of Clouds and Precipitation from Space: A Review, J. Atmos. Sci., 64, 3742-3765, doi:10.1175/2006JAS2375.1, 2007.

Stisen, S. and Sandholt, I.: Evaluation of remote-sensingbased rainfall products through predictive capability in hydrological runoff modelling, Hydrol. Process., 24, 879-891, doi:10.1002/hyp.7529, 2010.

Su, F., Hong, Y., and Lettenmaier, D. P.: Evaluation of TRMM Multisatellite Precipitation Analysis (TMPA) and Its Utility in Hydrologic Prediction in the La Plata Basin, J. Hydrometeorol., 9, 622-640, doi:10.1175/2007JHM944.1, 2008.

Su, Z.: The Surface Energy Balance System (SEBS) for estimation of turbulent heat fluxes, Hydrol. Earth Syst. Sci., 6, 85-100, doi:10.5194/hess-6-85-2002, 2002.

Sulla-Menashe, D., Friedl, M. A., Krankina, O. N., Baccini, A., Woodcock, C. E., Sibley, A., Sun, G., Kharuk, V., and Elsakov, V.: Hierarchical mapping of Northern Eurasian land cover using MODIS data, Remote Sens. Environ., 115, 392-403, doi:10.1016/j.rse.2010.09.010, 2011.

Szuster, B. W., Chen, Q., and Borger, M.: A comparison of classification techniques to support land cover and land use analysis in tropical coastal zones, Appl. Geogr., 31, 525-532, doi:10.1016/j.apgeog.2010.11.007, 2011.

Taşdemir, K., Milenov, P., and Tapsall, B.: A hybrid method combining SOM-based clustering and object-based analysis for identifying land in good agricultural condition, Comput. Electron. Agric., 83, 92-101, doi:10.1016/j.compag.2012.01.017, 2012. 
Tasumi, M., Trezza, R., Allen, R. G., and Wright, J. L.: U.S. Validation Tests on the SEBAL Model for Evapotranspiration via Satellite, in: Vol. 17, 54th IEC meeting of the international commission on irrigation and drainage (ICID) Workshop remote sensing of ET for large regions, 17 September, Montpellier, France, 1$14,2003$.

Teixeira, A. H. D. C. and Bastiaanssen, W. G. M.: Five methods to interpret field measurements of energy fluxes over a microsprinkler-irrigated mango orchard, Irrigation Sci., 30, 13-28, doi:10.1007/s00271-010-0256-y, 2010.

Teixeira, A. H. D. C., Bastiaanssen, W. G. M., Moura, M. S. B., Soares, J. M., Ahmad, M. D., and Bos, M. G.: Energy and water balance measurements for water productivity analysis in irrigated mango trees, Northeast Brazil, Agr. Forest Meteorol., 148, 1524 1537, doi:10.1016/j.agrformet.2008.05.004, 2008.

Teixeira, A. H. D. C., Bastiaanssen, W. G. M., Ahmad, M. D., and Bos, M. G.: Reviewing SEBAL input parameters for assessing evapotranspiration and water productivity for the Low-Middle São Francisco River basin, Brazil, Agr. Forest Meteorol., 149, 462-476, 2009.

Thenkabail, P. S., Schull, M., and Turral, H.: Ganges and Indus river basin land use/land cover (LULC) and irrigated area mapping using continuous streams of MODIS data, Remote Sens. Environ., 95, 317-341, doi:10.1016/j.rse.2004.12.018, 2005.

Thenkabail, P. S., Biradar, C. M., Noojipady, P., Dheeravath, V., Li, Y., Velpuri, M., Gumma, M., Gangalakunta, O. R. P., Turral, H., Cai, X., Vithanage, J., Schull, M. A., and Dutta, R.: Global irrigated area map (GIAM), derived from remote sensing, for the end of the last millennium, Int. J. Remote Sens., 30, 3679-3733, doi:10.1080/01431160802698919, 2009a.

Thenkabail, P. S., Turral, H., Biradar, C., and Lyon, J. G.: Remote sensing of global croplands for food security, CRC Press, Boca Raton, FL, 2009b.

Thoreson, B., Clark, B., Soppe, R., Keller, A., Bastiaanssen, W. G. M., and Eckhardt, J.: Comparison of evapotranspiration estimates from remote sensing (SEBAL), water balance, and crop coefficient approaches, in: ASCE World Environmental and Water Resources Congress 2009: Great Rivers, 17-21 May, Kansas City, 1-15, doi:10.1061/41036(342)437, 2009

Tovar, C., Seijmonsbergen, A. C., and Duivenvoorden, J. F.: Monitoring land use and land cover change in mountain regions: An example in the Jalca grasslands of the Peruvian Andes, Landsc. Urban Plan., 112, 40-49, doi:10.1016/j.landurbplan.2012.12.003, 2013.

Trambauer, P., Dutra, E., Maskey, S., Werner, M., Pappenberger, F., van Beek, L. P. H., and Uhlenbrook, S.: Comparison of different evaporation estimates over the African continent, Hydrol. Earth Syst. Sci., 18, 193-212, doi:10.5194/hess-18-193-2014, 2014

Tseng, M.-H., Chen, S.-J., Hwang, G.-H., and Shen, M.-Y.: A genetic algorithm rule-based approach for land-cover classification, ISPRS J. Photogramm. Remote Sens., 63, 202-212, doi:10.1016/j.isprsjprs.2007.09.001, 2008.

Twine, T. E., Kustas, W. P., Norman, J. M., Cook, D. R., Houser, P. R., Meyers, T. P., Prueger, J. H., Starks, P. J., and Wesely, M. L.: Correcting eddy-covariance flux underestimates over a grassland, Agr. Forest Meteorol., 103, 279-300, doi:10.1016/S01681923(00)00123-4, 2000.

UN: System of Environmental Economic Accounting for Water, Geneva, 2007.
Van der Walt, I. J., Struwig, A., and van Rensburg, J. R. J.: Forestry as a streamflow reduction activity in South Africa: Discussion and evaluation of the proposed procedure for the assessment of afforestation permit applications in terms of water sustainability, GeoJournal, 61, 173-181, doi:10.1007/s10708-004-2872-7, 2004.

Velpuri, N. M., Senay, G. B., Bohms, R. K., and Verdin, J. P.: A comprehensive evaluation of two MODIS evapotranspiration products over the conterminous United States: Using point and gridded FLUXNET and water balance ET, Remote Sens. Environ., 139, 35-49, 2013.

Venturini, V., Islam, S., and Rodriguez, L.: Estimation of evaporative fraction and evapotranspiration from MODIS products using a complementary based model, Remote Sens. Environ., 112, 132-141, doi:10.1016/j.rse.2007.04.014, 2008.

Verstraeten, W. W., Veroustraete, F., and Feyen, J.: Assessment of Evapotranspiration and Soil Moisture Content Across Different Scales of Observation, Sensors, 8, 70-117, doi:10.3390/s8010070, 2008.

Villarini, G., Krajewski, W. F., and Smith, J. A.: New paradigm for statistical validation of satellite precipitation estimates: Application to a large sample of the TMPA $0.25^{\circ}$ 3-hourly estimates over Oklahoma, J. Geophys. Res., 114, D12106, doi:10.1029/2008JD011475, 2009.

Voisin, N., Wood, A. W., and Lettenmaier, D. P.: Evaluation of Precipitation Products for Global Hydrological Prediction, J. Hydrometeorol., 9, 388-407, doi:10.1175/2007JHM938.1, 2008.

Vörösmarty, C. J., McIntyre, P. B., Gessner, M. O., Dudgeon, D., Prusevich, A., Green, P., Glidden, S., Bunn, S. E., Sullivan, C. A., Liermann, C. R., and Davies, P. M.: Global threats to human water security and river biodiversity, Nature, 467, 555-561, doi:10.1038/nature09440, 2010.

Wagner, W., Verhoest, N. E. C., Ludwig, R., and Tedesco, M.: Editorial "Remote sensing in hydrological sciences", Hydrol. Earth Syst. Sci., 13, 813-817, doi:10.5194/hess-13-813-2009, 2009.

Wang, J., Chen, Y., He, T., Lv, C., and Liu, A.: Application of geographic image cognition approach in land type classification using Hyperion image: A case study in China, Int. J. Appl. Earth Obs. Geoinf., 12, S212-S222, doi:10.1016/j.jag.2009.06.003, 2010.

Wang, J. R., Gogineni, S. P., and Ampe, J.: Active and passive microwave measurements of soil moisture in FIFE, J. Geophys. Res., 97, 18979, doi:10.1029/92JD00848, 1992.

Wang, K., Wang, P., Li, Z., Cribb, M., and Sparrow, M.: A simple method to estimate actual evapotranspiration from a combination of net radiation, vegetation index, and temperature, J. Geophys. Res., 112, D15107, doi:10.1029/2006JD008351, 2007.

Wang, Y. and Sun, D.: The ET estimation from ASTER image based on SEBAL and TSEB method, Proceedings of SPIE 6045, MIPPR 2005: Geospatial Information, Data Mining, and Applications, 604532, doi:10.1117/12.651845, 2005.

Waske, B. and Braun, M.: Classifier ensembles for land cover mapping using multitemporal SAR imagery, ISPRS J. Photogramm. Remote Sens., 64, 450-457, doi:10.1016/j.isprsjprs.2009.01.003, 2009.

Weiers, S., Groom, G., and Wissen, M.: Comparability and subjectivity of land cover maps pro- duced with digital image classification techniques?: some recent experiences from Denmark and 
northern Germany, Geogr. Tidsskr. Danish J. Geogr., 102, 59-77, 2002.

Whiteside, T. G., Boggs, G. S., and Maier, S. W.: Comparing object-based and pixel-based classifications for mapping savannas, Int. J. Appl. Earth Obs. Geoinf., 13, 884-893, doi:10.1016/j.jag.2011.06.008, 2011.

Wickham, J. D., Stehman, S. V., Gass, L., Dewitz, J., Fry, J. A., and Wade, T. G.: Accuracy assessment of NLCD 2006 land cover and impervious surface, Remote Sens. Environ., 130, 294-304, doi:10.1016/j.rse.2012.12.001, 2013.

Wilk, J., Kniveton, D., Andersson, L., Layberry, R., Todd, M. C., Hughes, D., Ringrose, S., and Vanderpost, C.: Estimating rainfall and water balance over the Okavango River Basin for hydrological applications, J. Hydrol., 331, 18-29, doi:10.1016/j.jhydrol.2006.04.049, 2006.

Winsemius, H. C., Savenije, H. H. G., and Bastiaanssen, W. G. M.: Constraining model parameters on remotely sensed evaporation: justification for distribution in ungauged basins?, Hydrol. Earth Syst. Sci., 12, 1403-1413, doi:10.5194/hess-12-14032008, 2008.

Wu, B., Yan, N., Xiong, J., Bastiaanssen, W. G. M., Zhu, W., and Stein, A.: Validation of ETWatch using field measurements at diverse landscapes: A case study in Hai Basin of China, J. Hydrol., 436-437, 67-80, 2012.

Wu, C., Cheng, C., Lo, H., and Chen, Y.: Study on estimating the evapotranspiration cover coefficient for stream flow simulation through remote sensing techniques, Int. J. Appl. Earth Obs. Geoinf., 12, 225-232, doi:10.1016/j.jag.2010.03.001, 2010.

Yalew, S., Teferi, E., and Van Griensven, A.: Land Use Change and Suitability Assessment in the Upper Blue Nile Basin Under Water Resources and Socio-economic Constraints: A Drive Towards a Decision Support System, in: International Congress on Environmental Modelling and Software Managing Resources of a Limited Planet, Sixth Biennial Meeting, edited by: Seppelt, R., Voinov, A. A., Lange, S., and Bankamp, D., 1-5 July, Leipzig, Germany, 2124-2131, 2012.
Yang, Y., Shang, S., and Jiang, L.: Remote sensing temporal and spatial patterns of evapotranspiration and the responses to water management in a large irrigation district of North China, Agr. Forest Meteorol., 164, 112-122, doi:10.1016/j.agrformet.2012.05.011, 2012.

Zhang, J., Hu, Y., Xiao, X., Chen, P., Han, S., Song, G., and Yu, G.: Satellite-based estimation of evapotranspiration of an old-growth temperate mixed forest, Agr. Forest Meteorol., 149, 976-984, doi:10.1016/j.agrformet.2008.12.002, 2009.

Zhang, K., Kimball, J. S., Nemani, R. R., and Running, S. W.: A continuous satellite-derived global record of land surface evapotranspiration from 1983 to 2006, Water Resour. Res., 46, W09522, doi:10.1029/2009WR008800, 2010.

Zhang, X., Sun, R., Zhang, B., and Tong, Q.: Land cover classification of the North China Plain using MODIS_EVI time series, ISPRS J. Photogramm. Remote Sens., 63, 476-484, doi:10.1016/j.isprsjprs.2008.02.005, 2008.

Zhang, Y., Leuning, R., Hutley, L. B., Beringer, J., McHugh, I., and Walker, J. P.: Using long-term water balances to parameterize surface conductances and calculate evaporation at $0.05^{\circ}$ spatial resolution, Water Resour. Res., 46, W05512, doi:10.1029/2009WR008716, 2010.

Zhu, Z., Woodcock, C. E., Rogan, J., and Kellndorfer, J.: Assessment of spectral, polarimetric, temporal, and spatial dimensions for urban and peri-urban land cover classification using Landsat and SAR data, Remote Sens. Environ., 117, 72-82, doi:10.1016/j.rse.2011.07.020, 2012. 